\title{
THE TAX TREATMENT OF A DISPOSITION OF PROFESSIONAL GOOD WILL
}

\section{TOBIAS WEISS $†$}

TAx planning for the professions and other personal service enterprises ${ }^{1}$ has been a lure for much of the finest legal talent. Particular attention has been given to the retirement of the owners of a professional practice and the ultimate disposition of their interests. ${ }^{2}$ The good will owned or controlled by the participants invariably becomes a principal consideration in such dispositions. In contrast to other assets stamped for tax purposes by their origin in personal service, good will conventionally has been viewed as an opportunity for realizing capital gain rather than ordinary income. ${ }^{3}$ The consequences of a disposition of professional good will therefore occupy a focal position in many of the plans proposed to minimize the taxation of professional practitioners.

Despite the extensive interest of tax planners in professional good will as a means of achieving capital gains, little analysis has been made of the premises on which their forecasts are constructed. Taxpayer counselling services, perhaps reticent to suggest questions which might jeopardize the advantages which their advice purports to bestow, have done little to stimulate inquiry. While the Internal Revenue Service might be expected to be less inhibited, its activity in this area has been fragmentary, difficult to understand, and limited to responses to particular taxpayer provocations. The courts have merely reflected the stereotypes which both taxpayer representatives and the Service have adopted from areas of illusory similarity.

From each of these sources the approach to the subject of professional good will has been molded by the concepts and rules applied to industrial or commercial good will. In essence, good will is a compact judgment of future earnings, a reduction to present value of expected future income. ${ }^{4}$ In a business venture, good will commonly attaches to an aggregate of nonpersonal objects, tangible or intangible, such as real estate or fixed assets or a brand name. In a professional venture, however, such property is typically of minimal importance; instead, the practitioner himself is the primary fount of good will. This

† Member, Connecticut and District of Columbia Bars.

1. Although the term "profession" is used in its commonly accepted meaning to include all of the learned pursuits, the discussion applies as well to any personal service business, such as that of a broker or an insurance agent. The patron or customer will generally be called the "client."

2. The interest in preparing for a participant's withdrawal from a personal service venture, whether on retirement or death or some other occasion involving a termination or reduction of his interest, has caused an outbreak of activity on several fronts. See, e.g., the recently enacted Self-Employed Individuals Tax Retirement Act of 1962, INT. REv. CODE OF 1954, § 401 ; and recent state statutes permitting professional practice in association or corporation form, note 140 infra.

3. Tenen, Tax Problems of Service Partnerships, N.Y.U. 16TH Inst. ON FEd. TAX. 137-67 (1958); Willis, Handbook of Partnership Taxation $\$ 30.08$ (1957) (discussing general problems of partnership taxation); John W. Wolcott, 39 T.C. 538 (1962).

4. See Heath, Property Vahation Problems and the Accountant, 117 Jours. or Accountancy 54 (1964); Note, 63 Colum. L. Rev. 1528 (1963). 
distinction between property and person, regardless of the criticism which may be leveled at it, is well entrenched in tax dogma; it has been consistently recognized that liability for future income can be severed by transferring the property out of which the income grows, whereas future income from personal service is beyond severance from the transferor. ${ }^{5}$ In an attempt to convey professional good will, it only obscures the implications of the personal nature of such good will and impedes an understanding of the proper tax treatment to view the transaction in the same manner as a conveyance of industrial or commercial good will.

Determining whether a disposition of professional good will is productive of capital gain or ordinary income requires a consideration of a broad array of fundamental questions. In probing these problems, the ensuing discussion explores the implications of two groups of standards. An initial inquiry will seek to develop the standards which ought to be used in isolating and identifying more closely the thing which is loosely labeled professional good will, as well as in analyzing what happens when its transfer is attempted. Thereafter, by considering the applicable principles of taxation and applying them to three principal classes of purported good will dispositions, it should be possible to determine whether profits from good will dispositions ought to be treated as capital gain or ordinary income.

\section{The Nature of Professional Good Will}

\section{Professional Good Will as a Transferable Asset}

The separable and disposable nature of the good will of a practitioner of a profession was the subject of consideration and controversy before the Federal income tax was adopted, ${ }^{6}$ and has continued to come into question after that time in respects unrelated to taxes. ${ }^{7}$ Many courts have been inclined to deny the existence of such good will as a transferable commodity, reasoning that it is the embodiment of the skill, experience and personality of the practitioner,

5. Lucas v. Earl, 281 U.S. 111 (1930); Commissioner v. Tower, 327 U.S. 280 (1946); Pelham G. Wodehouse, 8 T.C. 637 (1947), rev'd on other grounds, 178 F.2d 987 (4th Cir. 1949).

6. McCurry v. Gibson, 108 Ala. 451, 18 So. 806 (1895) (physician) ; Cook v. Johnson, 47 Conn. 175 (1879) (dentist) ; Hoyt v. Holly, 39 Conn. 326 (1872) (physician) ; Poh1man v. Dawson, 63 Kan. 471, 65 Pac. 689 (1901) (barber) ; Smith v. Smith, 51 La. Ann. 72, 24 So. 618 (1898) (insurance agency); Foss v. Roby, 195 Mass. 292, 81 N.E. 199 (1907) (dentist); Tierney v. Klein, 67 Miss. 173, 6 So. 739 (1889) (insurance agency); Read v. Mackey, 47 Misc. 435, 95 N.Y. Supp. 935 (Sup. Ct. 1905) (broker); Cowan v. Fairbrother, 118 N.C. 406, 24 S.E. 212 (1896) (newspaper publisher).

7. Smith v. Bull, 50 Cal. 2d 294, 325 P.2d 463 (1958) (advertising agency - conversion action on partnership split-up); Mueller v. Mueller, 144 Cal. App. $2 d 245$ (1956) (dental laboratory - property division on divorce); Evans v. Gunnip, 36 Del. Ch. 589, 135 A.2d 128 (1957) (CPA - accounting on partnership split-up) ; Harshbarger v. Eby, 28 Idaho 753, 156 Pac. 619 (1916) (physician - action to recover sale price); Siddall v. Keating, S App. Div. 2d 44, 185 N.Y.S.2d 630 (1959) (lawyer - accounting on partnership split-up) ; Durio v. Johnson, 68 N.M. 82, 358 P.2d 703 (1961) (veterinarian - action for sales price); Macfadden v. Jenkins, 40 N.D. 422,169 N.W. 151 (1918) (real estate agency - accounting for sales proceeds). 
enveloping his relationship with his clients, and as such is no more separable from him than his reputation. ${ }^{8}$ Such a view continues to persist in some places, and is reflected, for example, in the restriction, as a matter of internal professional regulation, against the sale by lawyers of their professional good will. ${ }^{2}$ Other jurisdictions recognize that a professional practitioner who enjoys the allegiance of clients can take measures, which other practitioners consider to be of value and for which they are willing to pay good consideration, to influence the transfer of that allegiance to another member of the same profession. ${ }^{10}$

An insight into the merits of these views may be suggested by identifying the "good will" with which they deal. While the intangible nature of good will has lent itself more readily to a variety of extended commentary than precise definition, ${ }^{11}$ for the practitioner of a profession it can be identified essentially as the desire on the part of his clients to continue to seek his services. ${ }^{12} \mathrm{~A}$ sale of that good will is an attempt to shift that future client patronage to another practitioner. Future client favor, in the best of circumstances, cannot be taken as a certainty, but must be approached rather in terms of probability : and, where an effort is made to transfer the patronage, that probability is likely to be affected. ${ }^{13}$

8. Cook v. Lauten, 1 III. App. 2d 255, 117 N.E.2d 414 (1954) (CPA); Smith v. Smith, 51 La. Ann. 72, 24 So. 618 (1898) ; Pollock v. Ralston, 5 Wash. 2d 36, 104 P.2d 934 (1940) (sales agency) ; Siddall v. Keating, 8 App. Div. 2d 44, 46-47, 185 N.Y.S.2d $630,632-33$ (1959) (lawyer).

9. American Bar Association, Committee on Professional Ethics and Grievances, Opinion 266 (June 21, 1945) ; DRINKER, Legal Ethics 161, 189 (1953). These restrictions apply to a sale to a buyer who is not a partner of the seller, and as to such cases Opinion 266, supra, declares that "Clients are not merchandise. Lawyers are not tradesmen. They have nothing to sell but personal service. An attempt, therefore, to barter in clients would appear to be inconsistent with the best concepts of our professional status."

10. Cf. Smith v. Bull, 50 Cal. 2d 294, 325 P.2d 463 (1958); Evans v. Gunnip, 36 Del. Ch. 589, 135 A.2d 128 (1957) ; Foss v. Roby, 195 Mass. 292, 81 N.E. 199 (1907); Slack v. Suddoth, 102 Tenn. 375, 52 S.E. 180 (1899). As to sale of good will by lawyers in England, see Payment for Partnership Goodwill, 227 THE LAw Times 145 (1959). There is no professional prohibition in the United States against sale of a CPA practice. CAREY, Professional Ethics of Certified Public Accountants 206 (1956); but ef. Lynch v. Baily, 275 App. Div. 527, 532, 90 N.Y.S.2d 359, 363, aff'd 300 N.Y. 615, 90 N.E.2d 484 (1949).

11. Rev. Rul. 59-60, 1959-1 Cum. Buld. 237, 241 ; 2 Paul, Federal. Estate and Gift TAXation $\$ 18.16$ (1942); McDonald, Goodwill and the Federal Inconte Tax, 45 VA. L. REv. 645 (1959) ; Note, An Inquiry Into the Nature of Goodwill, 53 CoLuM. L. REv. 660 (1953).

12. See Cowan v. Fairbrother, 118 N.C. 406, 411, 24 S.E. 212, 212-13 (1896), stating that a professional "often creates an intangible but valuable property by winning the confidence of his patrons and securing immunity from successful competition for their business." See, e.g., the statutory definitions in CaI. Bus. AND Prof. Code § 14100; Mont. Rev. Codes Ann. \$ 67-1111 (1963); Okla. Stats. AnN. tit. 60, § 315 (1949). Cf. Menendez v. Holt, 128 U.S. 514, 521-22 (1888).

13. "It is the sale of a mere chance that a preference which has usually been extended will continue." Johnson v. Friedhoff, 7 Misc. 484, 486, 27 N.Y. Supp. 982 (Sup. Ct. 1894). See also Harshbarger v. Eby, 28 Idaho 753, 761, 156 Pac. 619, 621 (1916); Finch v. Michael, 167 N.C. $322,324-25,84$ S.E. 458,460 (1914). 
Whether professional good will can be transferred, therefore, is not a question which can be answered by formulating an absolute rule either affirming or denying its fungible character in all cases. In some professions, such as public accounting, good will appears to be more susceptible to transfer than in others, such as law or medicine, and within any profession the degree of transferability can be determined only in the context of the specific circumstances of the practitioner, his clients, and the purchaser. ${ }^{14}$ From this standpoint, the individual situation must be examined not only to see whether there exists any transferable good will at all, but, accepting an approach based on degrees of transferability, to determine the extent to which such good will is present and the amount of the purchase price reasonably allocable to it. ${ }^{15}$

Of the two lines of cases, then, the courts which adopt a rule that professional good will is transferable, acknowledging that the opportunity of client succession is an element of some value, often come closer to reality, although occasionally they underestimate the impact of varying circumstances. Those of the opposing view, in dogmatically emphasizing the personal quality of professional good will, have insufficiently distinguished the end product from its source; they fail to recognize that developed good will may be severable even though its source may have been the personality of the practitioner. ${ }^{16}$

\section{Requirements for Disposing of Transferable Good Will}

Assuming that in a specific situation professional good will is a vendable commodity, it nevertheless is not automatically transferred by a contractual provision to that effect. The provision for a transfer of professional good will can only be made effective through accompanying steps which are reasonably calculated to produce a client severance and succession. ${ }^{17}$ Some supporting arrangement or factual pattern which shows in reality that a transferor definitively is parting with client patronage, or at least that plausible measures are being taken to shift that patronage to a transferee, is required. Whether the measures taken have a sufficient capacity to produce that result is ultimately a factual question to be answered in the context of the circumstances of the specific case.

A variety of factors may be relevant. The physical place of business may in some instances be significant in influencing the continued patronage of existing clients. ${ }^{18}$ The exclusive right to the use of the name of a practitioner or firm, or to refer to a transferee as the successor of a particular individual or firm, may be some basis for inducing continued client patronage. The records of the

14. See, e.g., Merle P. Brooks, 36 T.C. 1128 (1961).

15. Cf. Rev. Rul. 57-480, 1957-2 Cum. Bulc. 47.

16. See Smith v. Bull, 50 Cal. 2d 294, 302, 325 P.2d 463, 468 (1958); Laube, Good Will In Professional Partnerships, 12 CORNele L.Q. 303, 326 (1927).

17. Cf. Tierney v. Klein, 67 Miss. 173, 6 So. 739 (1889); Rice v. Angell, 73 Tex. 350, 11 S.W. 338 (1889) ; Pollock v. Ralston, 5 Wash. 2d 36, 104 P.2d 934 (1940) ; Rodney B. Horton, 13 T.C. 143 (1949).

18. John Sumers, 36 T.C. 467 (1961); cf. Smith v. Davidson, 198 Ga. 231, 31 S.E.2d 477 (1944); Morris Zeltzerman, 34 T.C. 73, aff'd per curian, 283 F.2d 514 (1st Cir. 1960). 
practitioner may have value in the effort to channel clients to a successor. ${ }^{19}$ Even in the absence of such factors, an agreement for a shift in good will may nevertheless be a realistic one in the context of a history of client relations which shows little erosion of client patronage and points to the element of service rendered to clients, rather than to the person of the particular practitioner, as the more persuasive factor in retaining that patronage. ${ }^{20}$

It would appear, however, that none of these factors is likely to shift professional good will significantly without a concomitant commitment on the part of the transferor, which is either obligatory under law or at least voluntarily observed, to abstain from seeking the patronage of the clients which is the subject of the good will transfer. ${ }^{21}$ In a commercial or manufacturing enterprise in which plant or equipment, sales outlets, an employee organization, or the attributes of a physical product are the most important elements in attracting customers, or where an intangible such as a process or a trade name not dependent on the person of the vendor is the basis of customer acceptance, good will may be transferable through the conveyance of the one or more of these objects through which it is controlled. But the professional practitioner usually has no such external artifact in which his good will is embodied. His good will is dependent rather on his continuing personal relations with his clients. A purported transferor, left free to continue to do business with those clients, can seriously disrupt or negate his transferee's efforts to retain the clients, regardless of the configuration of other factors. The putative transferor thereby may keep himself poised to compete effectively for the future allegiance of those clients and substantially to retrieve that which he has allegedly surrendered. It would be difficult, if not impossible, to identify in such circumstances a measurable shift in professional good will. In order to assure an ascertainable severance of such good will, therefore, the arrangement normally should be accompanied, regardless of the other elements of the transaction, by an obligation or undertaking of the transferor not to complete for the patronage of those clients; alternatively there should at least exist a practical equivalent in the form of circumstances which eliminate the possibility of such competition.22

An express covenant not to compete represents such an obligation. ${ }^{23}$ Where

19. George J. Aitken, 35 T.C. 227 (1960) ; Edward A. Kenney, 37 T.C. 1161 (1962); Savings Assurance Agency, Inc., 32 P-H Tax Ct. Mem. 225 (1963).

20. Boe v. Commissioner, 307 F.2d 339 (9th Cir. 1962) (group medical practice); Merle P. Brooks, 36 T.C. 1128 (1961) (clinical orthodontist practice).

21. Cf. Yandell v. United States, 315 F.2d 141 (9th Cir. 1963); but of. Commissioner v. Killian; 314 F.2d 852 (5th Cir. 1963), affirming T.C. Memo. 1961-83.

22. Cook v. Johnson, 47 Conn. 175, 36 Am. Rep. 62 (1879); Rutan v. Coolidge, 241 Mass. 584, 136 N.E. 257 (1922). See Hunt v. Street, 182 Tem. 167, 174, 184 S.W.2d 553, 555 (1945). Cf. Yandell v. United States, 208 F. Supp. 306 (D. Ore. 1962); Blake, Employee Agreements Not to Compete, 73 HARv. L. REv. 625, 646-47, 652 (1960); Miller, Capital Gains Taxation of the Fruits of Personal Effort: Before and Under the 1954 Code, 64 YaLe L.J. 1, 33 (1954).

23. Cook v. Johnsorr, supra note 22; Kohlman v. Dawson; 63 Kan. 471, 65 Pac. 689 (1901) ; Cowan v. Fairbrother, 118 N.C. 406, 24 S.E. 212 (1896); cf. Rutan v. Coolidge, 241 Mass. 584, 136 N.E. 257 (1922). 
there is a disposition of a practice without such an express covenant, there may be a question whether the covenant nevertheless should be inferred from the purported transfer. ${ }^{24}$ If under local law the omission is thus cured by judicial construction, ${ }^{25}$ it generally should suffice to sustain an attempt to transfer good will. There are courts, however, which are reluctant to interpolate in this manner in order to cure the omission of an express obligation, ${ }^{26}$ and in such event, barring circumstances with substantially equivalent effect, the alleged good will transfer normally would be ineffective. In the absence of an express or implied covenant, competition nevertheless may be substantially eliminated as a result of circumstances such as the disability or death ${ }^{\mathbf{2 7}}$ of the practitioner or his permanent removal to a distant location. Such de facto restrictions may produce approximately the same effect for purposes of establishing a transfer of professional good will as a covenant not to compete. $^{28}$ There have even been situations in which, absent an express covenant or equivalent circumstantial safeguard, a practitioner has nevertheless voluntarily refrained from professional relations with old clients or sought to persuade them to patronize his successor, and this voluntary abstention or affirmative assistance has been found sufficient to support an enforceable promise to pay for good will. ${ }^{20}$

\section{Total Disposition of Good Will}

A sale of a professional practice normally includes an agreement for the total, immediate disposition by the seller of his good will. This is the simplest case of a professional good will disposition, in which the severance requirement just discussed can be readily satisfied by the seller. The intention of the parties is that the seller should withdraw completely from the practice, surrendering entirely and as promptly as possible his control of his clients and

24. 1 Barkett \& Seago, Partners and Partnerships 187-89 (1956); 2 Rowley, PARTNERShIPS $\$ 45.6$ (2d ed. 1960).

25. Foss v. Roby, 195 Mass. 292, 81 N.E. 199 (1907).

26. See Evans v. Gunnip, 36 Del. Ch. 589 , 135 A.2d 128 (1957).

27. Alfred Muerlin, 25 T.C. 118 (1955); cf. Savinge Assurance Agency, Inc., 22 CCH Tax Ct. Mem. 200 (1962), finding in its special circumstances that a transfer of an insurance business could not include a transfer of good will where the proprietor had already died.

28. Cf. Ray H. Schulz, 34 T.C. 235 (1960), aff'd, 294 F.2d 52 (9th Cir. 1961); Blake, supra note 22 at 655 .

29. Hoyt v. Holly, 39 Conn: 326, 12 Am. Rep. 390 (1872) ; Evans v. Gunnip, 36 Del. Ch. 589, 135 A.2d 128 (1957). Cf. the companion cases of Herbert M. La Rue, 37 T.C. 39 (1961) and Charles H. Girt, 30 P-H Tax Ct. Mem. 1637 (1961). Whether a purported transfer of good will should be recognized for tax purposes where it is dependent on such voluntary behavior is seriously questionable, at least until after a period of sufficient duration substantially to duplicate for the transferee the opportunities which would have resulted if the transferor had bound himself with a covenant not to compete. In such cases it would appear proper to view the transaction in terms of the analogy of a unilateral contract which arises only after the promisee has completed performance of his part of the bargain; and, under this analysis, the operative dispositive event would occur not at the time the parties made their arrangement but when this period of forbearance or performance had elapsed. 
his enjoyment of their patronage. An immediate severance may not always occur, however, some ties between the seller and the practice being retained for transitional purposes either at the insistence of the buyer or the seller. But these purposes are identifiable; the participation of the seller continues on a much modified scale and for only a relatively short time. ${ }^{30}$

The amount of the consideration paid for the good will is often measured by the anticipated earnings of the practice, as by a multiple of one year's income or of average income over a longer period. Once the amount is thus determined, the fact and time of payment may be unrelated to the income of the transferor's practice, as where the payment is made in a single lump amount or in a variety of installments which are obligatory independent of the earnings of the practice. In addition, however, the payment itself may be conditioned on the presence of future earnings from the transferee's practice, being cast as a percentage of the income which is to be earned by the practice. Despite the measurement and dependence of the payment on future earnings of the practice, even to the point of being a share of those earnings and thereby assuming the operating risks of reduced or nonexistent earnings, the severance requirements for a transfer of the good will can be met under the standards heretofore discussed. On a complete withdrawal by the transferor, regardless of the method of payment, client control can be shifted, the transferor can divest himself of proprietary authority, and the transferee can take full command of the practice.

A further element, through which payment for good will is dependent upon future earnings, is sometimes present in such transactions. The transferor may be deemed to have made a profit sharing arrangement with the transferee, as a result of which he continues to be involved in the practice. It may thus be said that this continuing interest prevents any asserted withdrawal and sale of good will. Assuming a satisfaction of the nontax standards, it might prove helpful further to dissect the transaction into two phases, the first of which is a disposition of the good will, and the second of which is a placement of the sales proceeds at the risk of the practice. A sale of the good will would then be recognized, but in addition the seller would be found to have thereafter assumed a new position as an inactive partner or an investor or a creditor of the practice. In that event, the subsequent payments out of the income of the practice consist of a capital element, the recovery of the initial proceeds, and an income element, the return of those proceeds in some form.

\section{Partial Disposition of Good Will}

There are recurring situations in which only a partial disposition of professional good will is claimed to have been made. Satisfaction of the severance requirements becomes considerably more difficult where the intended transfer is limited to a portion of the transferor's good will or where the transfer, although involving all the good will, is deferred to some future time rather

30. These transitional arrangements are considered in connection with partial dispositions in the text at note 45 infra. 
than being effective when the arrangement is made. The first of such dispositions is partial in a quantitative sense, purporting immediately to split off a portion of the volume of good will; the second is partial in a temporal sense, dividing the time continuum in order to keep the entire good will in the transferor for a stipulated period. A combination of these types may also be encountered, as illustrated by an arrangement between two practitioners under which there is an asserted present sale of a portion of the good will and a transfer of the balance at a later date.

The quantitative partial disposition has appeared in two basic forms. In one, the transferor attempts to sever completely his good will while retaining the good will of other clients and continuing to engage actively in his practice. For example, an accountant ${ }^{31}$ or an orthodontist ${ }^{32}$ with several independent offices at separate locations may sell one office and its good will. In effect, however, a total immediate disposition is being made of the patrons at that office, and as to that segment no further considerations are involved. Rather than splitting off one of these offices through a sale, the transferor and transferee may form a partnership, with the transferor remaining in one office and the transferee supervising another one, at which he assumes a dominant operating position and control of client relations. Again, the transferor can sever his ties with the patrons of the latter office in accordance with the standards for a total immediate disposition. ${ }^{33}$ In a second and more frequent kind of partial disposition, the transferor in effect purports to share with other persons some portion of his good will with the same clientele, so that the transferor and transferee claim to enjoy jointly and simultaneously the favor of the same patrons. This is a more complex feat to achieve.

These partial dispositions, purportedly involving a concurrent sharing or a deferred severance of good will, have certain distinctive features. At the time the dispositive arrangement is made, the claimed transferor does not as

31. Estate of Masquelette v. Commissioner, 239 F.2d 322 (4th Cir. 1956).

32. Merle P. Brooks, 36 T.C. 1128 (1961).

33. The accuracy of this analysis of the situation is particularly clear where each participant's profit share is somehow confined or substantially related to the income from the office he supervises, and in reality that is often likely to be the effect of the arrangement. It is possible, however, for profits from all the offices to be pooled and for a division of the profits to be made which has no strong relationship to office income, and as a result of which, particularly where an established senior is admitting an anxious junior, the profit division is weighted in favor of the senior so as to preserve for himself a portion of the profit enjoyment of the office whose good will was sold. Thus, enjoyment of the good will may in some measure be retained even though control has been surrendered. In such a case the severance of control is the predominant factor, however, which dictates a finding that, as a matter of fact, there has been a disposition of the good will of that office. In the absence of control, the senior's continued enjoyment is at the mercy of the transferee and bears some resemblance to the transaction consisting of a total disposition for a consideration based on a share of the profits from the practice sold, discussed in the text following note 30 supra.

The situation in essence would be the same where the practice has only one office, but the seller and buyer who are forming a partnership agree on a transfer of control over specific clients who theretofore had been part of the seller's clientele. 
a rule separate himself from the good will which is the subject of the arrangement, but continues in a position to control and enjoy it. Consequently, he remains, behind the facade of a disposition, strategically situated to retain the allegiance of the clients involved. This deliberate continued participation of the alleged transferor makes it inconsistent to expect him to enter into a simultaneous and immediately effective covenant not to compete for the business of those same clients. It is not logical in these circumstances, moreover, to infer a comparable restriction against competition for that business. It is therefore questionable, under the standards heretofore postulated, whether any good will severance has occurred.

To give content to these general observations, it is helpful to refer briefly to some specific situations in which partial dispositions are characteristic. A senior practitioner may take in a junior as a partner, for which the junior makes some payment ${ }^{34}$ which variously is assigned to fixed assets, receivables, work-in-process, or good will. At this juncture of the union the conditions for a severance of the senior's good will ordinarily are not met. In order to protect and preserve his economic security, the senior's customary intent at that time is retention rather than severance of the good will of his clients. ${ }^{35}$ Even though the junior may in fact render the service and have substantial relations with the clients, the senior is usually careful to maintain at least his basic contacts with them and to remain in a position to influence their future allegiance. ${ }^{36}$ To be sure, junior, if he is resourceful and the conditions are opportune, may himself successfully exploit these contacts and eventually wean away client allegiance. But seen at the inception of the union,

34. A payment need not always be made by the junior or other new entrant into such a combination. An aging single practitioner, without receiving any payment, may want a partner in order to protect against the hazards of disability, to furnish continuity of service at other times of absence, and to create a prearranged market for the sale of his practice at his death. In the absence of a payment in money or other property, however, there is no occasion for a capital gain and the problems here discussed do not arise.

35. Compare the comment made with respect to the recently enacted Self-Employed Individuals Tax Retirement Act of 1962, INT. REv. CoDE of 1954, § 401 : "The bill singles out for assistance a class of people, the self-employed, who as a group are, generally speaking, least in need or deserving of assistance. The doctor, lawyer, or small businessman is not forced to retire at a specified age. He typically builds up a practice or business, takes in younger associates, and continues to benefit from such practice or business well beyond the earning years of the average employee." Minority views of Senators Douglas and Gore, S. REP. No. 992, 87th Cong., 1st Sess. 56 (1961).

36. Comapre the Self-Employed Individuals Tax Retirement Act of 1962, INT. Rev. CODE of 1954, § 401, under which the earned income of a self-employed practitioner is construed to include fees received with respect to services rendered by subordinates. The applicable conditions are put as follows:

Under this concept of "earned income", the entire amount received by a self-employed individual as professional fees or commission will be treated as earned income if the taxpayer is engaged in the practice of a profession, such as medicine or law, even though he employs assistants to perform part or all of the services, provided the patients or clients are those of the taxpayer and look to him as the person: responsible for the services rendered.

S. REP. No. 992, 87th Cong., 1st Sess. 12 (1961). 
the possibility of such a shift is speculative and not susceptible to measurement and certainly not the product of an intentional grant by the senior. The common experience is that the senior, who stays on independently or for a prolonged period, neither isolates himself from his clients nor dissolves his favored ties with them nor abstains from cultivating their future patronage. In such circumstances there appears to be insufficient factual basis for recognizing a disposition of good will by him.

The admission of a junior as a partner may be motivated by the senior's desire to expand his practice by tapping additional business available to him through his established reputation. The junior fills his requirement for further manpower, being professionally qualified but lacking a client-following. When the junior makes a payment, purportedly for good will, at the outset of such a combination, it is unlikely that the senior, in exchange, intends to shift his client ties to the junior. Indeed, it is doubtful, even if he intended otherwise, that the senior could restrict himself for that purpose without substantially damaging the capacity of the partnership to attract patronage, in view of its special dependence on the reputation and position of the senior as the key to the additional business needed to sustain the junior and make the operation profitable. The junior's initial payment is rather for the good will which the senior retains and intends to cultivate and for the senior's related personal services in bringing in the clients, or at least for the use of his name on behalf of the combination very much as in the case of a payment made for the use of a trade mark or a trade name. The payment may also be viewed as an advance to the senior against future profits to be earned from the expanded practice, representing an anticipatory realization of partnership profits. The senior thereby increases his effective share of the income, while the junior will be reimbursed from the portion of those profits which they have agreed to attribute to him. ${ }^{37}$ In no event is the payment likely to be made for an actual shift in good will.

The established practitioner is often in a position to influence a client's choice of a specialist or a practitioner in a contiguous area. The general practitioner in law frequently finds that his clients need qualified tax advice; the general dentist with a large children's practice is usually in the initial position to detect the need for and recommend orthodontic service; the obstetrician, developing a bond of confidence with his patients, can sway the selection of a pediatrician. Payments made to practitioners for their referrals or recommendations in such situations would clearly represent compensation for services rather than payment for transfer of good will. ${ }^{38}$ Where the actual or potential volume of referrals is large, both professional stature and monetary

37. The compensatory benefit to the senior may be in some form other than money or its equivalent, as where the senior receives a larger share of current profits or contributes lesser services with the intent of reducing the extent of his activity or arranges a means for the disposition of his interests on death. But, as noted in note 34 supra, in the absence of some payment the capital gains problem here discussed is not presented.

38. See Merle P. Brooks, 36 T.C. 1128, 1135 (1961) ; cf. Lilly v. Commissioner, 343 U.S. 90 (1951). 
return may well indicate a partnership or group practice to be more advantageous than a pattern of reference between separate practitioners, and again the superior economic position of one of the parties may result in a payment to him purportedly for good will. The basic nature of the payment, however, remains unaltered despite the change in the relationship between the parties: in essence, it is still compensation for referral services. The professional work involved being of a type which the payee in no event can perform, the good will of his own practice is not involved and a transfer of his own client patronage in his area of competence is not included. The most that he can do is to route to others, practicing either separately or together with him, business which they can and he cannot handle; it is for this referral service that the payments are made.

In some professions, as in the case of an animal hospital of a veterinarian, ownership of the physical facility is a prominent factor in fixing client patronage. Because of this interdependent relationship, the good will is not likely to be sold without a simultaneous sale of the facility, though the good will may be paid for separately. Where the owner of such a practice retains the facility but purports to sell part of his good will, the disposition of good will is probably specious, the seller in fact maintaining client control through the facility and reinforcing that position through his continued participation in the practice. An alleged partial disposition of good will is more likely to be accompanied by a corresponding sale of an interest in the facility. Such a disposition, of a partial interest both in the facility and in the good will, approaches the situations heretofore described in which a separable segment of a practice is effectively split off. In those situations, however, the seller severed all ties with the clients patronizing the segmented portion; here, despite the importance of the facility, personal relations with clients constitute a significant factor and the seller remains in an influential position through those continuing relations to affect client patronage. Nor is this situation, because of the presence of this personal element, in the same category as a partial disposition of physical plant and good will in a manufacturing enterprise, as a result of which the buyer acquires an interest in an end product. The professional practitioner would put himself more in the position of such a seller if he were to deprive himself of the future use of his name with respect to client patronage, and, as a consequence, really satisfy the standards heretofore described for a severance and transfer of professional good will. But a practitioner is not likely to disable himself to that extent unless he contemplates complete withdrawal from the practice, and the continuing participant will not be found to undertake such extensive restraints. While the presence and importance of the physical facility is a hybrid factor tending to make it more difficult to ascertain whether a disposition of professional good will has really been made, the applicable standards remain the same, and the burden ought to be put on the party asserting a disposition to show that those standards have been satisfied.

Just as a senior may bring in a junior, two or more practitioners in an existing partnership may admit additional members. These may be juniors who come in on the same terms as have been described with respect to the 
single senior who takes on a junior, in which event the considerations heretofore described are applicable, or instead the new members may be persons of greater maturity and more advanced professional and economic development. A single practitioner likewise may form a partnership with one or more other individuals who are more closely his equal than his junior. Despite these variations in the economic and professional levels of the participants, their basic motivation remains unchanged: to protect his fundamental economic position each of them with a client-following normally will seek to retain extensive control over the continued allegiance of his own clients.

In many of these combinations - after the parties are satisfied as to their compatibility and capacity to function profitably - a formal agreement may be executed binding each participant to transfer his good will to the others at his retirement or death. ${ }^{39}$ Often a specific date for retirement during lifetime is not fixed, and withdrawal due to death is uncertain as to time, so that the point at which the good will transfer is to occur is entirely indeterminate. In other agreements, however, a specific retirement date may be fixed, as where a senior undertakes to withdraw after a specific period and to leave his practice to the junior, so that the time of the good will transfer becomes more definite. In a third arrangement, a transfer of good will is required if the party is still a member of the combination at the time of his death or retirement, whenever it may occur, but he is left free at any prior time to withdraw from the combination, together with his clients, before either of those events occurs, Finally, such arrangements may contain a covenant not to compete effective with the purchase of a partner's interest at retirement or death, though not operative with respect to the promissor's own clients before the occurrence of one of those events.

The choice made among these variables in a partnership agreement, regardless of how it otherwise affects the parties, is not likely to establish a good will severance at the time the arrangement is made. At that time the good will transfer is at best only prospective, and with respect to a particular practitioner may never be consummated. In the meantime, each potential transferor remains in a position to control and enjoy the good will of his clients. Any intervening informal shift of client favor through association is likewise usually contrary to the parties' mutual intent, and in any event is too speculative to merit recognition. A recognizable conveyance of good will occurs, if at all, only at a later date when the prospective transfer is converted into a present effort to shift client allegiance, as marked by an immediately operative covenant not to complete, or its circumstantial equivalent.

The fact that a stranger is willing to pay for the opportunity to join with another practitioner is strong evidence that some benefit of actual or potential value is sought from the payee. A present severance in client allegiance, however, is not typically part of that benefit where the payee intends to continue

39. Provisions in such agreements may deal as well with circumstances which are treated as tantamount to retirement, such as a permanent major disability or a deliberate failure to attend to the affairs of the practice. As a matter of internal professional regulation, sale of good will to a partner may be permitted despite a prohibition against its sale to a stranger. See note 9 supra. 
actively in the practice for a substantial period. In some instances the benefit is in the form of an opportunity to enter a new area of endeavor, or to become expert or more qualified in one in which the payor already has some training. The principal benefit may consist of an opportunity to obtain a greater volume of work and to realize a greater income than the payor would be able to achieve without the aid of the payee and the business which the payee can attract. ${ }^{40}$ In such cases there may also be a vague expectation, or an informal understanding or even a formal agreement, that the payor will be the heir to the practice on the retirement of the payee or at his earlier death, but the effect on good will of any such arrangement is, as has been observed, prospective rather than present. If there is some degree of client favor acquired by the payor in the interim, it is usually nebulous and of uncertain duration, and as a practical matter is likely to become definite and important only when the payee is removed as a counteracting force.

In seeking assurance that these advantages will be made available, the payor may insist on the imposition of an express contractual obligation on the payee to contribute his good will to the joint practice. Such a commitment may restrict the rights of the contributor and subject him to a monetary penalty on its breach, but does not of itself establish a good will severance. In one case, ${ }^{41}$ as an example, two persons formed a food brokerage partnership, one of them having been in that business for thirty-five years and having built up good will of substantial value. He agreed to contribute that good will to the partnership, without entering into a covenant not to compete, and in return $\$ 5,000$ was paid to him by the other party. After six months the partnership was dissolved by mutual agreement, and the good will contributor then carried on the business himself, apparently utilizing his old contacts. In an action for a partnership accounting brought against him by his erstwhile partner, it was held that he was under a duty to account and pay for the partnership good will, which included good will initially contributed by him.42 Applying to this case the standards developed heretofore to test a severance of good will, none appears to have occurred at the time the $\$ 5,000$ payment was made. ${ }^{43}$ Despite

40. See Paynent For Partnership Goodwill, 227 TaE LAw Times 145 (1959); Rees v. United States, 187 F. Supp. 925 (D. Ore. 1960), aff'd per carriam, 295 F.2d 817 (9th Cir. 1961).

41. Whitman v. Jones, 322 Mass. 340,77 N.E.2d 315 (1948).

42. In valuing the appropriated good will, the court relied on the rules declared by it in Hutchins v. Page, 204 Mass. 284, 290, 90 N.E. 565, 567 (1910), in which that value was "estimated as it would have been if disposed of at a judicial sale, that is, at its value, with the right of the plaintiff to set up a competing business among the customers of the firm and others." Whitman v. Jones, 322 Mass. 340, 344, 77 N.E.2d 315, 317-18 (1948).

43. In considering alternative approaches to the issue in the case, it is germane in this connection that the court was willing to "lay to one side the contention of the plaintiff that the $\$ 5,000$ paid to the defendant at the time the partnership was formed was payment for a one-half interest in the good will which the defendant had built up in the business previously conducted by him individually. It is just as reasonable to infer that this sum was paid by the plaintiff for the privilege of entering into a partnership with one who had had greater experience in this type of business." Whitman v. Jones, 322 Mass. 340, 343, 77 N.E.2d 315, 317 (1948). 
the penalty imposed in the form of damages, the party contributing the good will retained control of his clients and was able to retain their business to the exclusion of his partner, and he apparently continued to enjoy their patronage unmolested after paying the monetary penalty. ${ }^{44}$ These circumstances scarcely spell a severance of his good will.

\section{Transitional Arrangements}

In the case of a total, immediate sale of good will, the parties may agree on a transition period during which the transferor will remain in association with the transferee, in order to induce clients to continue their patronage and become accustomed to the shift in practitioners. A relationship of this type is different from the participation of a transferor which accompanies a partial disposition of a professional interest. An association with a transferor for transitional purposes commonly restricts the transferor to an inactive role, or at least to a position without controlling or proprietorship authority over the affairs of the practice. It is, furthermore, ordinarily of relatively short duration, ${ }^{45}$ and certainly does not extend for a period of proprietorship as long as ten years. Whether a particular prescribed period supports or contradicts a present sale of good will is a question of fact. A long period of active participation as a proprietor only means that, at its beginning, the practitioner is not ready to retire. ${ }^{46}$ In the interim, for a substantial period, such a practitioner has the same enjoyment and retains the same client ties, with the same opportunity to influence the allegiance of his clients, as the one who makes a partial disposition without a definite commitment as to his future retirement. These earmarks are absent from, and distinguish, a present total disposition facilitated by a transitional participation.

Similarly, the method of payment for the good will, as for other assets of the practice sold in a total immediate disposition, may be in installments, and during the period of payout the seller may retain some actual or conditional affiliation with the practice in order to secure the buyer's obligations. Here

44. Injunctive relief, preventing the senior practitioner from resorting to his old clients, would not seem to be practical in view of the relations with them which he properly retains in such situations. Cf. McCurry v. Gibson, 108 Ala. 451, 457-59, 18 So. 806, 808 (1895) ; Dills v. Doebler, 62 Conn. 366, 26 Atl. 398 (1892). He may expressly agree that, upon the termination of the partnership or his withdrawal from it, he will not do business with those clients. Usually, however, as has been noted in the previous discussion, no such restriction is undertaken by a senior participant. $C f$. Malcolm J. Watson, 35 T.C. 203 (1960).

45. Umstead v. United States, 63-1 U.S. Tax Cas. $\pi$ 88,316 (M.D. N.C. 1963), aff'd per curriam, 327 F.2d 659 (4th Cir. 1964) (5 years); Charles F. Phillips, 40 T.C. 157 (1963) (3 years) ; Edward A. Kenney, 37 T.C. 1161 (1962) (1 year) ; Herbert M. La Rue, 37 T.C. 39 (1961) (1 to 2 years); Richard S. Wyler, 14 T.C. 1251 (1950) (3 years). In Merle P. Brooks, 36 T.C. 1128 (1961), the pay-out was over 20 years, but the seller withdrew at the beginning of this period and did not continue in the practice.

46. Cf. Malcolm J. Watson, 35 T.C. 203 (1960), in which the finding of fact was made that one of the significant motives in making such a partial disposition was the purpose "to service adequately his expanding practice, the choice facing the petitioner being to take in partners or to restrict his practice." Id. at 204. 
continued participation arises at the seller's insistence rather than that of the buyer. The considerations in identifying a good will disposition are nevertheless the same. A genuine installment sale is usually spread over a relatively short period, the seller desiring to limit the time during which he leaves at the buyer's risk the consideration which he is to receive. ${ }^{47}$ Where the payout is of longer duration, the seller is not likely to remain as a proprietor during the entire extensive period of payout. Where the seller continues as an active proprietor for a period as long as ten years, the presence of installment payments is likely to be camouflage for a partial disposition in which a severance of good will occurs only at the end of that period.

\section{Recapitulation}

A determination of the merits of a claim of disposition of professional good will requires a factual analysis, and for that purpose the following nontax standards are illuminating:

(1) Professional good will is the desire on the part of a client to seek the services of a particular practitioner.

(2) Professional good will may be a disposable asset. Whether or not it actually is transferable in a particular case is a question of fact, not to be determined by any abstract proposition about the transferable nature of good will.

(3) The important standard in determining the existence of disposable professional good will is whether in the specific case the good will has a significant possibility of transfer, and not whether that possibility was consummated with appreciable success. It is the opportunity which initially is relevant, and not any particular degree of success in its consummation as to which the purchasing practitioner can only speculate regardless of the scope of his hopes. The actual outcome may have a bearing retrospectively, however, as evidence on the prospects at the outset of shifting the good will.

(4) The presence of potentially disposable good will is itself without significance unless it is also the subject of an actual disposition, and that disposition should be of sufficient substance to be identifiable as a severance. As a general rule, based on the factual consequences in most instances, there can be no such disposition unless the transferor is restricted through an express or implied covenant not to compete. That restriction must be of a scope appropriate to the interest in good will purportedly transferred.

(5) By conforming to the foregoing standards there can be made an immediate transfer of the total professional good will of a practitioner in a way which can be identified as a severance and ought to be recognized as a disposition. A similar result is possible with respect to an immediate disposition of a definitive portion of a practice and its good will.

(6) It is not possible to satisfy the foregoing standards by making an alleged partial disposition of professional good will, after which the asserted transferor remains for a substantial period in a position materially to control

47. Cf. Estate of Masquelette v. Commissioner, 239 F.2d 322 (5th Cir. 1956) (5 years). 
or enjoy the patronage purportedly divested. Such a transaction is not identifiable as a severance, and ought not, therefore, be recognized as a good will disposition.

(7) Where there has been such a deferred disposition, the event of disposition occurs, if at all, only later, when there occurs an immediate severance either of all or of a definitive part of the good will in accordance with the foregoing standards.

\section{The Tax Treatment}

While determinations as to the presence or absence of professional good will and its disposition in a specific case can be made by an application of these nontax standards, such determinations do not by themselves dictate the proper income tax treatment which ought to be conferred. They must be evaluated in the context of accepted tax principles and techniques. After restating these criteria of income taxation, they can be applied to the significant characteristics revealed by the nontax standards, and the consequences can then be compared with the results reached by the Internal Revenue Service and the courts.

\section{The Tax Standards}

The pertinent tax standards are derived principally from the area of capital gains taxation. Two other spheres of recognized rules are also important, however. One concerns the effect given to certain assignments which purport to shift the ownership of income, and the other involves the weight accorded to control and enjoyment as factors in determining the incidence of income tax.

No very logical or consistent line differentiates ordinary income from capital gain. ${ }^{48}$ The statutory provisions are a welter of confusion, concession, and incertitude,,$^{48}$ and experts and theoreticians have been unable to find sufficient common ground to formulate a broadly acceptable concept of a capital gain and a method for its taxation..$^{50}$ In the face of so formidable a task, the attempt will not be made here to rationalize capital gains taxation. Rather, generally

48. See generally Cary, Pressure Groups and the Revemue Code: $A$ Requiem in Honor of the Departing Uniformity of the Tax Lazes, 68 HARv. L. REv. 745 (1955); Surrey, The Congress and the Tax Lobbyist - How Special Tax Provisions Get Enacted, 70 Harv. L. Rev. 1145 (1957).

49. In some cases, capital gains treatment has been accorded as a convenient way of providing relief to certain types of income regarded, for one reason or another, as incapable of bearing the full burden of ordinary income taxation. In others, capital gains treatment has been provided in lieu of an explicit averaging device. In still other cases, the capital gains option has been made available as an incentive device. As a result, the differential tax treatment accorded capital gains has been extended to certain types of income representing compensation for personal services, to income arising from sales of assets representing the taxpayer's stock in trade, and to amounts representing the accelerated receipt of future income.

Jonnt Econonitc Committee, 87th Cong., 1st Sess., The Federai Revenue System: Facts and Problems 50 (1961).

50. See Seltzer, The Nature and Tax Treatarent of Capital. Gains and Losses ch. 4 (1951) ; Surrey, Definitional Problems in Capital Gains Taxation, 69 Harv. L. REv. 985 (1956); The Federal Revenue Systems Facts and Problems, supra, note 44 at 64-70; Lutz, Taxing Capital Gains, The Wall Street Journal, Feb. 7, 1963, p. 16, col. 4. 
acknowledged principles and rules will be accepted, and the inquiry will instead be directed to how a purported disposition of professional good will ought to fit into the existing body of law.

For this purpose, the following established tax standards should be taken into account:

a. The favored treatment of capital gains is an exception in the tax law, which is to be "narrowly construed so as to protect the revenue against artful devices." 52 The courts have stressed that a capital gain results from an appreciation in market value ${ }^{53}$ rather than the realization of a lump sum which otherwise in time would be derived in a form taxable as ordinary income. ${ }^{54}$

b. A capital gain can be obtained only from the disposition of a "capital asset," ${ }^{55}$ which, under the statute, must be "property" which, the Supreme Court has said, is to be narrowly construed..57

c. A disposition can give rise to a capital gain only if it is a "sale or exchange." 58 It is not entitled to recognition as such a disposition unless and until it works a real change in ownership, ${ }^{59}$ and retention of a right of use may prevent recognition as a sale. ${ }^{60}$

d. Income derived from the affirmative rendition of personal services is

51. Corn Prods. Ref. Co. v. Commissioner, 350 U.S. 46, 52 (1956).

52. Commissioner v. P. G. Lake, Inc., 356 U.S. 260, 265 (1958). Cf. Braunstein v. Commissioner, 305 F.2d 949 (2d Cir. 1962), aff'd, 374 U.S. 65 (1963); Donald B. Jones, 40 T.C. 249 (1963) ; James A. Wiltsie, 32 P.H Tax Ct. Mem. 1547 (1963).

53. Commissioner v. Gillette Motor Trans. Inc., 364 U.S. 130, 134 (1960) ; Commissioner v. P. G. Lake, Inc., 365 U.S. 260, 265 (1958) ; First Nat'l Bank v. Commissioner, 309 F.2d 587, 588 (8th Cir. 1962). Cf. Eisenstern, The Ideologies of Taxation 93-105 (1961).

54. In addition to the Lake (assignment of any oil payment out of a working interest), Gillette Motor (award for appropriation of use of facilities for limited period), and First National (assignment of an anuity prior to maturity) cases, supra note 53, see Hort v. Commissioner, 313 U.S. 28, 31 (1941) (payment received in cancellation of lease rental). See also Roff v. Commissioner, 304 F.2d 450 (3d Cir. 1962) (annuity assignment); Rosen v. United States, 288 F.2d 658 (3d Cir. 1961) (original issue discount on maturity of investment contract); Commissioner v. Phillips, 275 F.2d 33 (4th Cir. 1960) (sale of endowment policy); Commissioner v. Morgan, 272 F.2d 936 (9th Cir. 1959) (original issue discount on maturity of investment contract) ; Fisher v. Commissioner, 209 F.2d 513 (6th Cir. 1954) (sales price of obligation attributable to defaulted interest); Rhodes' Estate v. Commissioner, 131 F.2d 50 (6th Cir. 1942) (sale of dividend rights); Arnfeld v. United States, 163 F. Supp. 865 (Ct. Cl. 1958), cert. denied, 359 U.S. 943 (1959) (annuity assignment).

55. INT, REV. CODE OF 1954, § 1222.

56. INT. REv. CODE of 1954, § 1221. A right to receive ordinary income is not "property" for this purpose. See note 49 supra.

57. Corn Prods. Ref. Co. v. Commissioner, 350 U.S. 46, 52 (1956).

58. INT. Rev. Code of 1954, § 1222.

59. Cf. Higgins v. Smith, 308 U.S. 473 (1940); Lucas v. North Texas Lumber Co., 281 U.S. 11 (1930); Albert E. Dyke, 6 T.C. 1134 (1946) ; M. Greenspun, 3 CCH Tax Ct. Mem. 341 (1944), aff'd in part and rev'd in part on other grounds sub nom. Commissioner v. Greenspun, 156 F.2d 917 (5th Cir. 1946).

60. Stalker Corp. v. United States, 209 F. Supp. 30 (E.D. Mich. 1962) ; Cf. Du Pont v. Commissioner, 118 F.2d 544 (3d Cir.), cert. denied, 314 U.S. 623 (1941). 
compensation taxable as ordinary income, ${ }^{01}$ as is income received for the abstention from personal effort, such as in the case of consideration received for a covenant not to compete. ${ }^{62}$

e. A disposition of a right to render services or to receive compensation for services rendered does not result in capital gain but is rather a conversion of future ordinary income into present ordinary income. ${ }^{63}$ Personal services are not "property," 4 and the disposition of such rights frequently is open to question as a sale or exchange. 65

f. Personal effort may create a product, tangible or intangible, which is recognized as a capital asset and the disposition of which is accorded capital gain treatment. ${ }^{60}$ Particularly with respect to intangible assets, it may be difficult to distinguish a payment for the asset from one for the services creating the asset. ${ }^{67}$

g. Where a transaction involves both a disposition of a capital asset and a payment in the nature of compensation, the two will be treated separately and the payment relating to each will be taxed accordingly ${ }^{68}$ but where the consideration relating to each element is not ascertainable and therefore not separable, and where the compensation feature predominates, the entire transaction will result in ordinary income. ${ }^{69}$

h. Good will is considered to be a capital asset, the sale of which at a profit

61. Int. Rev. CoDe of 1954, § 61(a) (1) ; Commissioner v. Duberstein; 363 U.S. 278 (1960) ; Ansorge v. Commissioner, 147 F.2d 459 (2d Cir. 1945) ; Frank Hodus, 14 T.C. 1301 (1950).

62. Ullman v. Commissioner, 264 F.2d 305 (2d Cir. 1959) ; Beals' Estate v. Commissioner, 82 F.2d 268 (2d Cir. 1936) ; Copeland v. Ratterree, 57-2 U.S. Tax Cas. II 58-193 (N.D.N.Y. 1957) ; Tate v. Knox, 131 F. Supp. 514 (D. Minn. 1955) ; Victor H. Heyn, 39 T.C. 719 (1963) ; Max Levine, 31 P-H Tax Ct. Mem. 410 (1962).

63. United States v. Woolsey, 326 F.2d 287 (5th Cir. 1963) ; United States v. Eidson, 310 F.2d 111 (5th Cir. 1962); Holt v. Commissioner, 303 F.2d 687 (9th Cir. 1962); Gordon v. Commissioner, 262 F.2d 413 (5th Cir. 1958), affirming 29 T.C. 510 (1957); Roscoe v. Commissioner, 215 F.2d 478 (5th Cir. 1954); Maryland Coal \& Coke Co. v. McGinnes, 64-1 U.S. Tax Cas. If 9262 (E.D. Pa. 1964); Glenn E. Alexander, 34 T.C. 758 (1960); Irving R. Lewis, 19 T.C. 887 (1953). But cf. Nelson Weaver Realty Co. v. Commissioner, 307 F.2d 897 (5th Cir. 1962).

64. Apart from judicial interpretation (see note 49 and 51 supra), this conclusion may be required by the statutory exclusion in INT. REv. CoDE of 1954, \$ 1221 (4).

65. See United States v. Eidson, 310 F.2d 111 (5th Cir. 1962) ; Holt v. Commissioner, 303 F.2d 687 (9th Cir. 1962) ; Wiseman v. Halliburton Oil Well Cementing Co., 301 F.2d 654 (10th Cir. 1962); Commissioner v. Starr Bros., 204 F.2d 673 (2d Cir. 1953). Contra: Jones v. Corbyn, 186 F.2d 450 (10th Cir. 1950).

66. The Heil Co., 38 T.C. 989 (1962) ; Calley and Clark Co. v. United States, 63-2 U.S. Tax Cas. II 90,031 (S.D.W.Va. 1963) ; Dunn, The Transfer of Know-Hoze to Controlled Corporations, 39 TAxes 571 (1961).

67. Cf. Walker v. United States, 62-1 U.S. Tax Cas. I 83,930 (W.D. Pa. 1961) Harold L. Regenstein, 35 T.C. 183 (1960); Arthur C. Cope, 12 CCH Tax Ct. Mem. 525 (1953); Rev. Rul. 64-56, 1964 INr. Rev. Bull. No. 13 at 11; Rev. Rul. 59-325, 1959-2 Cum. Bull. 185.

68. Spence v. United States, 156 F. Supp. 556 (Ct. C1. 1957) ; Arthur C. Ruge, 26 T.C. 138 (1956); Milton A. Bissell, 18 CCH Tax Ct. Mem. 1034 (1959).

69. See Harry L. Bialock, 35 T.C. 649, 662 (1961); Green v. Allen, 67 F. Supp. 1004,1006 (M.D. Ga. 1946). Cf. Walker v. United States, 62-1 U.S. Tax Cas. If 83,930 
results in capital gain, ${ }^{70}$ even though the value of good will depends on anticipated earnings. ${ }^{71}$

i. Where a taxpayer is entitled to receive compensation for services at a future date and makes a gift of it by an anticipatory assignment, he realizes the income and is taxable on it as much as if he had collected the income and paid it over to the object of his bounty. ${ }^{72}$

j. A transferor remains taxable on the income from property despite a shift in its technical ownership, if the transferor in effect retains control or dominion over the property or the income from the property. ${ }^{73}$

k. A transferor who retains the benefit or enjoyment of property will be treated as the owner of the property for tax purposes despite a disposition of title ownership. ${ }^{\mathbf{7 4}}$

\section{Effect of Covenant Not to Compete}

Under these tax standards, ${ }^{75}$ payment for a covenant not to compete results in ordinary income, as compensation in return for an abstention from personal effort. In no event can the tax standards for capital gain treatment ${ }^{70}$ be satisfied with respect to such a payment, even though the payment may represent a capital expenditure for the payor. ${ }^{77}$ In view of the pivotal position which a

(W.D. Pa. 1961) ; Estate of Paul L. Mitchell, 18 CCH Tax Ct. Mem. 1168 (1959); Raymond M. Hessert, 6 CCH Tax Ct. Mem. 1190 (1947).

An undivided amount was allocated by the court between good will and a covenant not to compete in Umstead v. United States, 63-1 U.S. Tax Cas. 88316 (M.D.N.C. 1963), aff'd per curiam, 327 F.2d 659 (4th Cir. 1964); Levine v. Commissioner, 324 F.2d 298 (3d Cir. 1963). See Note, Tax Treatment of Covenants Not to Compete: A Problem of Purchase Price Allocation, 67 Y ALE L.J. 1261 (1958).

70. Rev. Rul. 55-79, 1955-1 Cum. Bul.. 370; McDonald, Goodzwill and the Federal Income Tax, 45 VA. L. Rev. 645 (1959) ; Note, 53 Colum. L. Rev. 660 (1953). See Big Four Industries, Inc., 40 T.C. 1055 (1963).

71. Illustrating the close correspondence between good will and earnings, see Haberle Crystal Springs Brewing Co. v. Clarke, 30 F.2d 219 (2d Cir. 1929), rev'd, 280 U.S. 384 (1930) ; Donal A. Carty, 38 T.C. 46 (1962) ; Edward A. Kenney, 37 T.C. 1161 (1962); Rev. Rul. 59-60, 1959-1 Cum. Bulz. 237, 241 ; Stern, Planning Continuation of Accountant's Practice, 100 Trusts and Estates 20 (1961); Nice, The Professional Life Underweriter and Goodwill, 16 Journ. Soc. Chartered LIFe Underwriters 66 (1962); Hearn, Insurance Agencies - Income Tax Consequences Upon Termination of Agency Business, 40 TAXES 655 (1962).

72. Lucas v. Earl, 281 U.S. 111 (1930); Helvering v. Eubank, 311 U.S. 122 (1940); cf. Harrison v. Schaffner, 312 U.S. 579 (1941) ; Commissioner v. Tower, 327 U.S. 280 (1946). But cf. Blair v. Commissioner, 300 U.S. 5 (1937); Paul A. Teschner, 38 T.C. 1003 (1962).

73. Commissioner v. Sunnen, 333 U.S. 591 (1948); Helvering v. Clifford, 309 U.S. 331 (1940); Corliss v. Bowers, 281 U.S. 376 (1930); White v. Fitzpatrick, 193 F.2d 398 (2d Cir. 1951); Stanton v. Commissioner, 189 F.2d 297 (7th Cir. 1951).

74. Schoenberg v. Commissioner, 302 F.2d 416 (8th Cir. 1962).

75. See note 62 supra.

76. See notes 51 through 59 supra.

77. Schill v. United States, 207 F. Supp. 639 (W.D. Wash. 1962) ; Balis v. United States, 139 F. Supp. 930 (Ct. Cl. 1956) ; C. E. Silling, Sr., 27 T.C. 701 (1957). Disallowing depreciation on a purchased professional interest, see Boe v. Commissioner, 307 F.2d 339 (9th Cir. 1962) ; John Sumers, 36 T.C. 467 (1961) ; cf. Savings Assurance Agency, Inc., 22 CCH Tax Ct. Mem. 200 (1963). 
covenant not to compete or some qualifying equivalent occupies in the transfer of professional good will, the conclusion would seem to be inescapable that the profitable disposition of such good will involves a realization of ordinary income by the transferor.

Yet doubt has been cast on this simple thesis by the tax treatment and the accompanying semantics which the courts have evolved with respect to a covenant not to compete undertaken in connection with a disposition of a business and its good will. In such a situation the consideration paid for the covenant has been deemed conventionally to be a capital receipt if the covenant has been found to be "ancillary" to the transfer of the good will of the business, whereas ordinary income is the result if the covenant has been found to be "severable" from the good will. ${ }^{78}$ The same rules have been carried over, mechanically and without critical scrutiny, to the sale of a professional practice and its good will.78

But this treatment, where the covenant is deemed to be "ancillary" in character, ignores the vital element of personal service underlying the covenant even where it applies to a mercantile or commercial establishment, in which the factor of personal service tends to be less prominent than in a professional practice. These rules are therefore a patent departure from settled tax standards governing the tax treatment of compensation. This abnormality is justified on the ground that the "ancillary" covenant is inseparably bound up with the good will and with the aggregate of assets transferred by the seller, and is an indispensable incident for the effective transfer of those assets. Therefore, the tax coloration of the covenant is determined as though it were an indistinguishable part of good will. ${ }^{80}$ It is nevertheless the fact in most of these cases in which the parties deem it desirable to include a covenant as part of their bargain, that something significant has been paid for the covenant; therefore, regardless of any possible difficulties in valuation, the tax standards should be respected by at least requiring an allocation of the portion of the consideration attributable to the covenant. ${ }^{81} \mathrm{~A}$ more basic objection, however, is the false nature of the distinction drawn by these rules, for, as a

78. Edward A. Kenney, 37 T.C. 1161 (1962); Barnet, Covenants Not To Compete: Their Effects Upon the Covenantor and Covenantee, N.Y.U. 18TH INST. oN FED. TAx. 861 (1960).

79. Estate of Masquelette v. Commissioner, 239 F.2d 322 (5th Cir. 1957) ; Malcolm J. Watson, 35 T.C. 203 (1960); Richard S. Wyler, 14 T.C. 1251 (1950); Rodney B. Horton, 13 T.C. 143 (1949).

80. Commissioner v. Gazette Telegraph Co., 209 F.2d 926 (10th Cir. 1954) (dictum); Aaron Michaels, 12 T.C. 17 (1949); Toledo Newspaper Co., 2 T.C. 794 (1943); cf. Howard G. Mathews, 20 CCH Tax Ct. Mem. 1565 (1961) (dictum), aff'd per curiam, 311 F.2d 795 (3d Cir. 1963).

81. Cf. Commissioner v. Maresi, 156 F.2d 929, 931 (2d Cir. 1946) (L. Hand, J.) : "The one sure way to do injustice in such cases is to allow nothing whatever upon the excuse that we cannot tell how much to allow." See Toledo Blade Co., 11 T.C. 1079, 1086-87 (1948) (dissenting opinion).

An allocation was made in Levine v. Commissioner, 324 F.2d 298 (3d Cir. 1963) (fuel oil distributor); Umstead v. United States, 63-1 U.S. Tax Cas. $₫$ 88,316 (D.C.N.C. 1963). 
matter of economic reality, the covenant must always be "ancillary" and can never be "severable." To the extent that the assets of a business retain their earning power because the seller does not assume a competing position the covenant is "ancillary" to a transfer of the assets and the business good will; and, since the only value of such a covenant is to preserve that earning power, the covenant can be other than "ancillary" only in the rare case in which it has no purpose in substance. ${ }^{82}$ This fundamental fact cannot be altered by the manner of bargaining between buyer and seller, or the formal structure of their agreement, or the expressions of intent which they manifest. The result, if these rules were applied with economic candor in frank recognition of the uniform "ancillary" character of the covenant, would be to confer capital gains treatment in every case of a covenant given with the sale of a business.

Consequently, not only is a choice of alternatives in the traditional formulation irrational, but the resulting treatment indicated by following that formulation to its logical conclusion conflicts with settled tax standards relating to income from personal service. There is beginning to appear in the courts, moreover, some dissatisfaction with these traditional rules. But the effort so far has been confined to an attempt to reinterpret the conventional formulation while continuing to work within its limitations, ${ }^{83}$ rather than recognizing its underlying invalidity and scrapping it completely in favor of an approach founded on basic tax principles.

As much as these conventional rules are at odds with reality where an industrial or commercial enterprise is involved, they are even less defensible with respect to a professional practice. In the former there are identifiable tangible or intangible assets in which the business good will is embodied, with respect to which it may be argued that the covenant is incidental or "ancillary."

82. 3B Mertens, Law of Federat. Income Taxation 150 (Zimet \& Weiss rev. ed. 1957), followed in Schulz v. Commissioner, 294 F.2d 52, 55 (9th Cir. 1961).

83. Departures have been indicated in the direction of determining whether the parties intended to allocate a portion of the sales"price to the covenant, regardless of whether their contract was arranged to make the covenant severable or whether the covenant was treated in a "separate and distinct manner." Annabelle Candy Co. v. Commissioner, 62-2 U.S. Tax Cas. 88, 316 (9th Cir. 1962), rehearing denied, 314 F.2d 1 (9th Cir. 1962); Schulz v. Commissioner, 294 F.2d 52 (9th Cir. 1961) (disregarding the formal severance of the covenant and related consideration in the written agreement of sale and treating the covenant as part of the good will sold) ; United Finance and Thrift Corp. v. Commissioner. 282 F.2d 919 (4th Cir. 1960) (disregarding the specific allocation in the contract and making a different apportionment, assigning part of the consideration to good will) ; Wilson Athletic Goods Mfg. Co. v. Commissioner, 222 F.2d 355 (7th Cir. 1955) (allocating a portion of the consideration to the covenant where it had an actual value, even though there was no segregation in the contract); Levine v. Commissioner, 324 F.2d 298 (3d Cir. 1963). But see Van Kirk v. United States, 63-1 U.S. Tax Cas. 87643 (D.C. Ore. 1963) ; Armstrong v. Erickson, 63-1 U.S. Tax Cas. 87690 (D.C. Ore. 1963).

84. Cf. The Heil Co., 38 T.C. 989 (1962). See also the observations of Judge Opper concurring in Merle P. Brooks, 36 T.C. 1128, 1135 (1961), with respect to accompanying affirmative efforts to be made by a seller of professional good will. But see Estate of Masquelette v. Commissioner, 239 F.2d 322 (5th Cir. 1956); and, as to services "merely ancillary to the sale," Ernest B. White, 32 P-H Tax Ct. Mem. 81 (1963) ; Alfred Muerlin, 25 T.C. 118 (1955). 
By contrast, there typically are no such assets of significance in a professional practice; instead, in accordance with the proposed analysis based on the nontax standards, the core element is itself the covenant not to compete or a qualifying substitute. The point of emphasis in the sale of the industrial or commercial business is on its assets; by contrast, the emphasis is reversed in the sale of a professional practice, so that it falls on the personal commitment of a covenant not to compete or an acceptable equivalent. The covenant not to compete accompanying the sale of a professional practice more closely resembles a covenant not to compete unconnected with a sale of business assets, and under traditional rules ought clearly to result in ordinary income.

\section{Effect of Code on Transfer of Good Will}

Where a profession is practiced in partnership form and the interest of a withdrawing partner is liquidated either on his retirement or death, there is a statutory provision which grants capital assets status for good will of the partnership if "the partnership agreement provides for payment with respect to good will." $\$$ s It may be asked whether the Internal Revenue Code as a consequence makes the good will of a professional partnership a transferable commodity. Such a simple stipulation in a partnership agreement should not necessarily compel the conclusion that good will actually has been transferred. Rather, this statutory provision, like others in the Code, ${ }^{86}$ appears to apply only on the assumption that a transfer has in fact occurred without foreclosing an inquiry into the existence of that fact. ${ }^{87}$ The existence and transfer of such good will as a factual matter should be ascertained not by the partnership agreement but in accordance with the nontax standards which have been described.

\section{Immediate Total Disposition of Good Will}

The simplest case of a purported disposition of professional good will, in which an immediate disposition of all of it is attempted, raises two prime questions with a bearing on the tax consequences to the transferor.

First, in view of the factual dependence of such a disposition on a covenant not to compete or an eligible substitute as disclosed by the nontax standards,

85. INT. REv. CoDe of 1954, § 736(b) (2) (B); Wrirs, op. cit. supra note 3 , $\$ 26.06$. See Karan v. Commissioner, 319 F.2d 303 (7th Cir. 1963) ; Jackson Investment Co., 41 T.C. 675 (1964).

That a personal service partnership can have transferable good will is recognized in Treas. Reg. $\$ 1.736-1(b)(7)$, example (3). Under the 1939 Code, the sale of a partnership interest was treated as the sale of a capital asset. Ayrton Metal Co. v. Commissioner, 299 F.2d 741 (2d Cir. 1962) ; Dorman v. United States, 296 F.2d 27 (9th Cir. 1961); John W. Lenney, 38 T.C. 287 (1962).

86. INT. REv. CODE OF 1954, §§ 741, 751.

87. Cf. Chatsworth Stations, Inc., P-H 1964 Tax Ct. Mem. ff 64,011. Cf. S. Rep. No. 1622, 83d Cong., 2d Sess. 395 (1954): "Where the partnership agreement provides for payments with respect to good will, such payments may not exceed the reasonable value of the partner's share of partnership good will." See V. Zay Smith, 37 T.C. 1033 (1962), aff'd, 313 F.2d 16 (10th Cir. 1962) ; Carol F. Hall, 19 T.C. 445 (1952) ; A. Rhett du Pont, 19 T.C. 377 (1952). 
the question arises whether the gain to the transferor can ever qualify as a capital receipt. The answer ought to be, for the reasons given in the previous discussion of the tax treatment of such a covenant, that as a general rule the character of the transaction precludes capital gain treatment. If this stand were adopted, there would be no need to press further the inquiry into the tax consequences of professional good will dispositions. But there is no record of such a position having been urged before the courts with a proper analytical foundation, ${ }^{88}$ and both the courts and the Internal Revenue Service have accepted capital gains treatment for the proceeds from the disposition of professional good will as an available alternative. ${ }^{89}$

The extent to which the Code's recognition of capital gains treatment for payments received for good will on the withdrawal from a partnership or on sale of a partnership interest ${ }^{90}$ forces this position upon the courts and the Service is questionable. It apparently was the legislative assumption that these provisions might apply to a professional partnership. ${ }^{91}$ There is no evidence, however, that Congress considered or even was aware of the nature of the transaction involved in a disposition of professional good will. The consideration received for a covenant not to compete - which is indispensable to a recognizable transfer of good will - properly ought not to be taxed as a capital gain, and it is doubtful that Congress, if the matter were called to its attention, would agree to breach established tax principles and treat such personal service income other than as ordinary income. ${ }^{92} \mathrm{~A}$ contrary interpretation not only would carve out a special exception to established law but would do so only in favor of partners, discriminating against identically situated individual practitioners or those using one of the new corporate forms authorized in many states. ${ }^{93}$ These are not consequences which are readily adaptable to a reasoned interpretation of the intent of Congress.

Secondly, how is a distinction to be made between the situations which are to qualify for capital gains treatment and those for which it should be denied, in view of the pre-eminent role of the covenant not to compete or some equivalent? Because the question must be postulated disregarding the proper recognition to be given to the non-competition covenant, a rational answer seems inherently impossible. This difficulty is reflected in part in the confusion and artifice found in the previously discussed tax rules developed by the courts in

88. Cf. Estate of Masquelette v. Commissioner, 239 F.2d 322, 325 (5th Cir. 1956); Richard S. Wyler, 14 T.C. 1251, 1259 (1950).

89. Total immediate dispositions were involved in the Masquelette and $W y l e r$ cases, supra note 88, and in the Horton case, 13 T.C: 143 (1949).

90. See notes 85 and 86 stipra.

91. See S. REP. No. 1622, 83d Cong., 2d Sess. 96-98, 403 (1954), using a personal service partnership to illustrate the application of these provisions.

92. Compare INT. Rev. CoDE of 1954 , $\$ \$ 671-78$, prescribing exclusive statutory rules as to when a grantor is taxable on the income from a trust, reith Treas. Reg. $\$ 1.671-1(\mathrm{c})$ (1956), stating that a grantor may be taxed on trust income under the anticipatory assignment rule.

93. See note 140 infra and accompanying text. 
dealing with the effect of a covenant not to compete. ${ }^{94}$ Nevertheless, for purposes of further inquiry the position of the courts, that the presence of a noncompetition covenant of itself does not bar capital gains treatment, may be accepted, and this question, concerned with distinguishing between qualifying and nonqualifying situations, can be recast as follows: When, in the particular circumstances, does a transaction occur which is entitled to capital gains treatment as an effective disposition of professional good will?

This question has drawn a vacillating reaction from the Internal Revenue Service. At first the Service took the position that for income tax purposes professional good will was not a transferable asset, and consequently that no portion of the sales proceeds on disposition of a practice could be allocated to good will, unless exclusive use of the individual or firm name were sold as well. $^{.5}$ This position was strenuously criticized and challenged, and the courts rejected it. ${ }^{96}$ In the light of the nontax law on professional good will as it has been analyzed above, the courts were correct; the position was unsound. If the income tax treatment were based on the view of those state courts which deny the transferable nature of professional good will, there would be no such asset to be transferred regardless of the accompanying disposition of a professional name. Assuming that in such circumstances payment nonetheless is made for the use of the name, it could have little value and not much of the sales proceeds could be attributed to it - since it could be shorn, by hypothesis, of the good will which those courts hold to be nontransferable. Similarly, where regulations of a professional association bar the outright sale of a name or prohibit a payment for good will, ${ }^{97}$ the transfer of a name clearly could not itself be the basis on which to predicate a payment allegedly made for good will. ${ }^{28}$ Taking the other approach, under which the income tax law would be based on the view that professional good will is a vendible asset, there would likewise be no warrant for making the transfer of a name an indispensable condition to the transfer of good will, the local courts of that persuasion not having imposed such a condition for a good will transfer. Indeed, if any one factor is to be required to establish a transfer of good will, it is not the professional name but the obligation, or one of the equivalents suggested earlier, to refrain from competing for the clients for whose favor payment is made.99

94. See notes 78,79 , and 80 supra.

95. Rev. Rul. 57-480, 1957-2 CuMr. Bulz. 47.

96. Estate of Masquelette v. Commissioner, 239 F.2d 322 (5th Cir. 1956), reversing 14 CCH Tax Ct. Mem. 879 (1955); Richard S. Wyler, 14 T.C. 1251 (1950); Rodney B. Horton, 13 T.C. 143 (1949); Ernest B. White, 22 CCH Tax Ct. Mem. 70 (1963).

97. See note 9 supra.

98. But cf. Savings Assurance Agency, Inc., $22 \mathrm{CCH}$ Tax Ct. Mem. 200 (1963), in which good will was found not to have been transferred because of the prior death of a sole proprietor and the cessation of active conduct of an insurance agency. A transfer of a name here might serve as the basis for a transfer of good will. Alfred Muerlin, 25 T.C. 118 (1955).

99. See the agreement made for the sale of an accountant's good will in: Estate of Lso MIlnik, 21 CCF Tax Ct. Mem. 67 (1961), aff'd sub nom. Karan v. Commissioner, 319 F.2d 303 (7th Cir. 1963); Hock, Personal Good Will, 37 Taxes 825, 836 (1959). 
The stand taken by the Service was therefore defective and vulnerable to criticism. And yet the thrust of its view was not completely groundless, in that it perceived that such good will could not be transferred - at least not to an ascertainable extent meriting tax recognition - without the corroboration and support of a proper concurrent arrrangement.

After being repulsed in the courts, the Service reluctantly ${ }^{100}$ acknowledged that in such cases there may be transferable good will in a professional practice and that it may be conveyed without an assignment of a name, but added enigmatically that this result could obtain only where the success of the practice was not dependent solely on the personal characteristics and competence of the owner. ${ }^{101}$ Since such personal factors commonly determine the experience of a professional practice, it is difficult to understand when transferable good will would ever exist within this limitation. In some situations clients may be attracted to an office or organization with little regard for the individuals with whom they deal, ${ }^{102}$ and success in such instances may be considered not to depend solely on the practitioner. But these represent a small minority of the cases in which the question of transferable professional good will is pertinent. Of course, the professional practitioner often has employees or assistants, and in a literal sense it can be said that his success is not dependent solely on himself. Such a standard would make little sense, however, and would appear not to be the guide which the Service intended. Under a third interpretation of the- Service directive, a practice would be deemed not to depend solely on the person of the owner where another practitioner another person - could carry on the practice as well and creditably discharge its professional requirements. ${ }^{103}$ The meaning of such a test, however, is not clear and, if it were the guide, would need refinement. It is usually possible to find a practitioner of ability and talent equal to that of the owner of the practice and who could service the clients as well as the owner, and cast in these terms, the standard could uniformly be satisfied and would therefore lose its practical importance. Such a test might prove more useful if it were put in terms of an inquiry into the probability that the old clients will patronize a replacement of equal ability, rather than assuming such a continuity in patronage. An affirmative answer would indicate that the successor could carry on the old practice in the sense that the practice would remain with him. In that sense the success of the practice would not depend on the personal characteristics of the predecessor, for, even assuming a close dependence on the predecessor, he might nevertheless be able to take steps reasonably calculated to shift a significant part of his clientele to the successor. ${ }^{104}$ If

100. See 1959-2 Cux. Bunc. 7, for the Commissioner's acquiescence in Rodney B. Horton, 13 T.C. 143 (1949); and Richard S. Wyler, 14 T.C. 1251 (1950).

101. Rev. Rul. 60-301, 1960-2 Cum. Bull. 15.

102. See, e.g., Boe v. Commissioner, 307 F.2d 339 (9th Cir. 1962) ; Merle P. Brooks, 36 T.C. 1128 (1961) ; John Sumers, 36 T.C. 467 (1961).

103. Cf. Hock, I.R.B. and Recent Cases Recognize that Good Will of a Professional is Salable, 14 Taxatron 34, 34-35 (1961).

104. See note 16 supra. 
the meaning of the present Service position is reduced to these terms, the existence of a sufficient probability of client transfer or the presence of adequate steps to accomplish such a transfer ought to return to the central elements which have been described previously in this analysis.

No opinion has yet been expressed by the courts about the new Service position. ${ }^{105}$ Apart from the matter of the transfer of the practitioner's name, there has been little perceptive analysis by the courts in tax cases of facts which may show whether a disposition of professional good will has occurred. Where capital gain treatment has been sustained, however, a covenant not to compete has been present in the parties' arrangement. ${ }^{106}$ Moreover, an administrative standard such as that now maintained by the Service and interpreted as last suggested, to require effective steps reasonably calculated to shift the transferred good will, would be consistent with those decisions.

The Service position should be clarified in a comprehensive directive dealing with professional good will, dispensing with the need for speculative interpretation, and reflecting the nontax standards propounded previously. The courts in turn ought to accept and articulate those standards. To do so would not onlv introduce the proper approach in this area but might also lead to a recognition of the determinative weight of the noncompetition arrangements, causing a reexamination and reformulation by the courts of the present tax treatment of a sale of professional good will.

\section{Partial Disposition of Good Will by Continuing Participant}

If the present rules are accepted, a total immediate disposition of professional good will can thus result in capital gain to the transferor. This result is postulated on the presence of an effective disposition, which the nontax standards show to be possible where there is a total immediate disposition. But those nontax standards have also been shown to reveal, with respect to a partial disposition, that: (a) In the case of a partial disposition which is essentially similar to a total disposition, as where an entire separate unit of practice is sold, the same conclusion applies that an effective disposition can be made. (b) Where there is a purported partial disposition of good will and the seller continues in the practice without a commitment for the disposition of the balance of the good will and his withdrawal at some fixed time, there has been no effective disposition until the actual withdrawal and completion of the disposition. (c) The factual characteristics of an alleged partial disposition with continuing participation by the purported transferor include: his uninterrupted control over the good will involved in the disposition: his unbroken enjoyment of the good will; the absence of a definitive, ascertainable severance of good will; the absence of a covenant not to compete or some equivalent arrangement which operates during the period of participation; and the rendition of personal services by him during that period for the benefit of

105. Rev. Rul. 60-301, 1960-2 Cum. Butc. 15, was discussed briefly and superficially in Malcolm J. Watson, 35 T.C. 203, 209-10 (1960), and was mentioned in Ernest B. White, 22 CCH Tax Ct. Mem. 70 (1963).

106. See, e.g., cases at note 96 supra. 
the party from whom he receives the consideration. Such an arrangement if more than an insignificant or formal share in the practice is retained manifests a desire and intent to continue actively in the practice.

The fact complex which characterizes such a transaction does not meet the usual tax standards for capital gain treatment. To the extent that the consideration is received for present or future personal services, the payment is not made for a capital asset, and cannot result in capital gain. The outcome is the same insofar as the payment is for an assignment of future ordinary income; there is only a conversion into present ordinary income. To the extent that the consideration may also include payment for a capital asset, the consideration allocable to such payment must be ascertainable and separately determinable. In fact it is not. Even if the portion allocable to the capital asset "good will" could be isolated, there is no disposition which rises to the status of a "sale or exchange" so long as substantial ties to the allegedly transferred asset are retained by the continuing participant. Indeed, the enjoyment and control remaining in the purported transferor indicate that no disposition entitled to recognition for tax purposes has occurred at the time of the formal partial disposition, and that in substance the continuing participant should be considered to continue his ownership of the good will. ${ }^{107}$

In harmony with basic tax principles, a payment received in these circumstances ought to be treated as ordinary income rather than capital gain. That conclusion is supported by $O^{\prime}$ Rear $v$. Commissioner, ${ }^{108}$ in which a lawyer, as a single practitioner, brought in two equal partners, each of whom paid him $\$ 25,000$ for his "excess value of good will and unearned fees." His continuation in the practice was essential to the arrangement; a covenant not to compete was not involved. He claimed that he had sold a capital asset, consisting of good will and the right to share in future profits, and reported none of these proceeds on the ground that they did not exceed the value of the asset on March 1, 1913. The Commissioner taxed the entire proceeds as ordinary income, contending that in reality they "represented the then present value of a two-thirds interest in the petitioner's expected future profits from his profession."100 In a perceptive opinion, itself affirmed on appeal, the Board of Tax Appeals sustained the Commissioner. Relying on the wording of the agreement between the parties, it found that a sale had not occurred because the payment was made only as a "differential" to compensate the senior man for the loss of a share of future profits to his less experienced and younger partners.

Because the language of the agreement in O'Rear was phrased in terms of "differential payment" rather than of a "sale," the remaining observations of both tribunals might be considered mere dictum. Yet those observations, particularly by the Board, apply to fundamental characteristics of the transaction, transcending the particular form of the O'Rear agreement. Thus the decision

107. See cases at note 73 supra; cf. State Street Trust Co. v. United States, 263 F.2d 635 (1st Cir. 1959).

108. 80 F.2d 473 (6th Cir. 1935), affirming 28 B.T.A. 698 (1933).

109. $80 \mathrm{~F} .2 \mathrm{~d}$ at 474 . 
should be taken as founded on the following factual characteristics to which attention was called: (a) There was no disposition of good will. First, it was doubted whether professional good will could be transferred unless the transferor refrained from practicing; and, second, the good will could not be transferred "piecemeal" to two others. ${ }^{110}$ The appellate court felt that in no event was the good will of a lawyer transferable, 111 but that position was more extreme than was necessary for the decision of the case. (b) Compensation for personal services was received "through an arrangement with partners whereby they advance certain amounts for the privilege of taking a larger share of the partnership profits than their personal contribution would otherwise justify."112

While the $O$ 'Rear case confirms the analysis proposed in this article, a more recent decision is diametrically opposed. In Rees $v$. United States, ${ }^{113}$ a well established orthodontist joined with two younger men to form a partnership in which each of them was to have an equal share. They agreed on a price of $\$ 35,000$ for an undefined interest in the good will of his practice, to be paid to him in equal monthly installments over a 10 year period. The parties arrived at this amount after considering the reputation of the senior man, his capacity to attract future business, and the earnings of his practice. The district court held this to be capital gain received on a sale of good will, and on appeal the decision was affirmed in reliance on the opinion of the lower court. The $O$ 'Rear decision was distinguished by the district court on the ground that the statements made there about the sale of good will were dicta, and the weight of that case was discounted on the basis of its age, having been decided before a more recent group of cases. ${ }^{114}$ But those cases involved a total rather than a partial disposition of good will, and therefore neither furnished precedent for the court in Rees, nor represented a development which made O'Rear obsolete. The latter and its observations were directly in point and should not have been dismissed summarily. On the question which really was in issue, the disposition of only part of the good will, the court simply said that the failure to sell the entire good will was of no significance. Analytically, therefore, the court was mistaken both in its result and in its reasoning.

The Service has ruled that it will not follow the Rees decision, indicating only that it conflicts with the $O^{\prime} R$ ear case and the established principle that an assignment of future earnings results in ordinary income. ${ }^{115}$ Earlier, while the Service still emphasized the professional name as the vehicle for transferring the good will, 116 it had declared that consideration would not be treated as received for the sale of good will where it was paid for a part interest in the practice and the right to use the transferor's name, if the transferor con-

110. 28 B.T.A. at 700-01.

111. S0 F.2d at 474 .

112. 28 B.T.A. at 701.

113. 187 F. Supp. 924 (D. Ore. 1960), aff'd per curiam, 295 F.2d 817 (9th Cir. 1961).

114. Caces cited at note 96 supra.

115. Rev. Rui. 62-114, 1962-2 Cum. Bull. 15, based on T.I.R. 388 (June 29, 1962), reflecting Rev. Rul. 57-480, 1957-2 Cum. Burl. 47.

116. See note 95 supra. 
tinued in the practice. ${ }^{117}$ Although properly hostile to the Rees case, these fragmentary expressions are insufficient as an administrative guide; therefore, a comprehensive directive should include a more extensive presentation of the features of the partial disposition and the reasons why they make the Rees case untenable.

Section 751 of the Code, discussed previously in connection with the total disposition of good will, ${ }^{118}$ confers capital gain treatment on the sale of "all or a part" of a partnership interest, including its good will. But capital gain treatment is no more appropriate here for what is essentially ordinary income resulting from a purported partial transfer than it was there. A disposition is first necessary 119 and is lacking in transactions of the kind involved in the O'Rear and Rees cases. Section 751 therefore does not alter the conclusions which have been reached.

\section{Partial Disposition of Good Will by Retiring Participant}

Rather than leave the transferor as a continuing participant with no fixed obligation for retirement, the parties may arrange a specific or determinable time at which the transferor will retire. Thus, a physician, at the time of the purported partial disposition of his practice, may provide contractually for the disposition of the balance of his good will and for his retirement ten years later. Should such a binding obligation for withdrawal in the future cause the payment made at the outset to be treated differently for tax purposes from what has been suggested with respect to a partial disposition by a continuing participant? If the observations which have been made with respect to the customary case of a partial disposition in which no limit on the period of participation by the "selling" practitioner is fixed are sound, then such an obligation to withdraw, with its execution fixed at some distant time in the future, presents no essential difference in fact and calls for no distinction in tax treatment. ${ }^{120}$

The presence or absence of an obligation for distant retirement does not alter the significant circumstances in the substantial intervening period. In the meantime the alleged transferor retains the same control and enjoyment of his original good will, and there is the same lack of an ascertainable severance of good will, as in the situation of the continuing participant uncommitted to retirement. While such a retirement obligation ultimately may compel a change in the transferor's relations to his clients, it does not do so in the many intervening years, during which he can continue to influence and use that patronage for his own profit. ${ }^{121}$ Such an arrangement is to be distinguished on its face from the sale of the entire professional good will for a consideration

117. Rev. Rul. 57-480, 1957-2 CuM. Bulc. 47.

118. See text accompanying notes 85 and 86 supra.

119. See text accompanying note 87 supra.

120. This conclusion and the observations made here apply as well to arrangements involving an obligation as to succession at a future time which is not definitely fixed but which may occur on the happening of an event, such as death or retirement.

121. Cf. note 46 supra. 
paid in installments, during the payment of which the seller normally remains in the practice for a relatively short period. ${ }^{122}$ Nor are these circumstances modified by a covenant of the transferor not to compete for the patronage of his clients, if the covenant does not begin to operate, as is likely to be the case, until the future withdrawal date arrives. Here, as in the situation of the purported transferor who continues in the practice without a retirement obligation, the nontax standards establish the fact of failure to make a disposition of good will at the beginning of the transaction, and payments received at that time ought to be denied capital gain treatment.

The essential similarity of these situations is further underscored by the ease with which, in most cases, the parties can shift from one form to the other, without sacrificing any of the substance of their affairs. If capital gain is denied to the party who does not undertake to retire, it would only invite evasion and undermine that denial to confer different treatment because of a provision for distant retirement. It is too often a simple matter to inject such a provision without frustrating the intentions or modifying the practical positions of the parties to a partial disposition, and, if a tax advantage weighed in the balance, it could be obtained conveniently through such a contractual formality. ${ }^{123}$ It would create an inconsistency to confer capital gain in one situation and not the other, and thereby would cause the adoption by indirection of the holding in the Rees case ${ }^{124}$ as the prevailing rule for the situation in which no arrangement is made to limit the duration of the continued participation. The inconsistency can be eliminated, of course, and the opportunity for such evasion removed, by an outright acceptance of the Rees case, but the resulting uniformity would mean no more than open resignation to erosion of tax principle on a broader scale.

The fixed-retirement situation was presented in Malcolm J. Watson.125 There, a certified public accountant, as a single practitioner, sold a 45 percent share in his practice to two other accountants with whom he formed a partnership, retained a substantial profits interest, and agreed to sell them the remaining 55 percent ten years later. Payment for the 45 percent share was measured in part by past earnings, and was to be made in part for an interest in the future earnings of the partnership. The two buyers were juniors who had been employed elsewhere and who did not appear to have clients of their own to any significant extent. The Tax Court rejected a contention that this payment was ordinary income from an assignment of a share in future earnings, and instead held it to be capital gain on the sale of good will. In substance the Tax

122. See text accompanying notes 45 and 46 supra.

123. The opposition of interests between the contracting parties, sometimes relied on as a safeguard to produce arrangements which are gemuine in substance and to minimize revenue loss, is absent here. The use of such a formality to get capital gain for the "transferor" does not cause an alteration in the tax position of the other party, whose payment in any event is likely to be treated as a capital expenditure. See Savings Assurance Agency, Inc., 22 CCH Tax Ct. Mem. 200 (1963).

124. See note 113 supra.

125. 35 T.C. 203 (1960). Cf. Commissioner v. Killian, 314 F.2d 852 (5th Cir. 1963). 
Court treated the arrangement as a total disposition of the practice, with the continued participation of the transferor as having no other major purpose than to assure the continued patronage of his clients. This reconstructed version by the Tax Court represented a reshaping of the facts into a mold significantly different from the actual situation before it, ignoring the ten-year period interposed before there could be a total disposition, overlooking the control and enjoyment in the transferor during this long intervening period, and exaggerating the extent to which the desire to transfer the good will was a responsible cause for the interjection of that period of continued participation.

The holding in Malcolm J. Watson is supported by the Rees case, in which the district court reached a compatible conclusion without going through the gyrations of the Tax Court in Watson. On the surface, Watson might appear to be an a fortiori decision, in that a finding of capital gain may seem more difficult to make in the absence of an obligation to retire than in the presence of such an undertaking. If capital gain is proper in Rees, it might seem unavoidable in Watson; and, conversely, it might appear that Rees may be rejected without reflection on the force of $W$ atson. Indeed, although the Service reacted sharply in renouncing the Rees result, an appeal filed from the Watson decision was withdrawn and as yet there has been no formal indication from the Service as to whether or not it acquiesces in it. In essence, however, the facts in these two cases display the same fundamental characteristics - at least up to a retirement date which is long deferred - and, for the considerations heretofore discussed, it would be undesirable and inconsistent to attempt to differentiate them. The rejection by the Service of the Rees decision should therefore caution tax planners that resistance may be encountered in the other area as well. The views of the Service on this subject should not be left to conjecture, however, and, as part of its comprehensive directive urged before, it ought to express and clarify its position, demonstrate the similarity of Watson and Rees, and find them equally unacceptable.

\section{Deferred Total Disposition of Good Will}

Where the formal arrangement between the parties consists of a deferred disposition of all the good will to some distant or indeterminate future time or occasion, rather than disposing of a part of it immediately or piecemeal in the interim, there is by hypothesis a future date at which the transfer will take place and when the transferor will sever completely his relations with his practice as a proprietor. If no payments are made until that event occurs in the future, the transaction should become at that time an immediate total disposition and be treated accordingly.

If either at the inception of the arrangement or at some interim point payment is made to the transferor, the transaction ought to be treated in the same fashion for tax purposes as a purported immediate or interim disposition of part of the good will plus the deferral of the balance until a later time. In form these transactions differ in that the latter, the partial disposition, produces the facade of a simultaneous transfer of good will with the initial or interim pay- 
ments, whereas the other is silent or even expressly provides that no interest in the good will is to pass until final payment is made. But in substance these transactions have an underlying resemblance, of the type described in connection with the nontax standards and to which reference has been made in preceding discussion of the tax consequences. The tax treatment therefore ought to be the same, the initial and interim payments being regarded as ordinary income.

As a practical matter, no such arrangements, involving a long deferral of the entire good will transfer, have been found, ${ }^{126}$ but they would appear soon enough if the difference in form were dignified with a difference in tax incidence. An arrangement for interim installment payments may be made as a method of financing a genuine total disposition, conceived and intended as such by the parties but involving some deferment in the transfer of technical ownership of the practice as a security device pending completion of the payments. As has been indicated previously, ${ }^{127}$ however, such a transaction would be factually distinguishable from those considered here.

\section{S. Total Disposition for a Share of Profits}

A total immediate disposition of the good will of a practice may be made for a consideration which is not only measured by the future profits of the practice but in its very payment is made conditional on the presence of such profits. The factual characteristics of such a transaction have been discussed, and it was observed that under the nontax standards a disposition may be viewed as being followed by a placement of the sales proceeds at the risk of the practice in return for a share of the profits. ${ }^{128}$

If the transaction is divided into two separable elements consisting of these two phases, capital gain treatment for the bulk of the consideration would be required under present tax law. At least where a seller has divested himself of his total interest in an asset, tax precedent recognizes that a sale can qualify for capital gain treatment notwithstanding a consideration consisting of a portion of the subsequent income from the asset. ${ }^{129}$ Recently there has even been congressional confirmation of this principle. ${ }^{130}$ Yet under an alternative approach, the profit sharing feature of the arrangement would preclude its division into two phases; both would be merged into a single transaction, for which there would be no recognition of a disposition because of the continuing

126. Cf. Merle P. Brooks, 36 T.C. 1128 (1961), in which there was a total immediate disposition but the consideration was to be paid at the rate of $\$ 1,000$ per month for 20 years. The seller, moreover, did not continue to act in the practice as a proprietor. The Service has acquiesced in this decision. 1962-2 Cum. Bull. 4.

127. See notes 45 and 46 sitpra; cf. Merle P. Brooks, supra note 126.

128. See discussion in text following note 30 supra; and Ernest B. White, 32 P.F Tax Ct. Mem. 81 (1963).

129. See the case law concerned with dispositions of copyrights and patents, discussed in 3B Mertens, Law of Federat Income Taxation $\$ \$ 22.132,22.133$ (Zimet \& Weiss rev. ed. 1958).

130. S. KEp. No. 830, 88th Cong., 2d Sess. 103 (1964), concerned with the addition of $\S 483$ to the 1954 Code by $\S 224$ of the Revenue Act of 1964, Pub. L. No. 272, 88th Cong., 2d Sess. (Feb. 26, 1964). 
economic interest of the transferor in the asset transferred. Thus, in an older case where a stock brokerage house contracted to attempt to transfer its customers to a similar house for a consideration consisting of 25 percent of the commissions to be received on securities sales to those customers during the next six years, the transaction was found to be a profit sharing arrangement productive of only ordinary income to the seller. ${ }^{131}$ The prevailing rules take a contrary approach, however, accepting the divisible nature of the two phases for tax purposes, and recognizing the presence of a good will disposition on a capital gain basis. ${ }^{132}$

Such treatment ought to be accompanied, in view of the second phase, by inclusion of a portion of the future payments as income representing an investment return. Before the 1964 Act, acceptance of the disposition as the focal point of the transaction would have made possible avoidance of that ordinary income through its conversion into capital gain. If the future payments were susceptible of reduction to present worth, the capital gain would have been computed with reference to that present value, which, as a result of a discount or interest factor, would be less than the face amount of the payment. ${ }^{133}$ The disposition would then have been treated as a closed transaction, and subsequent realization of the difference between the present worth and the face value would have been treated as a separate transaction resulting in ordinary income. ${ }^{134}$ But if the future payments were not reducible to present

131. Cassatt v. Commissioner, 137 F.2d 745 (3d Cir. 1943). The contention of a joint venture with a split fee arrangement was rejected in Ernest B. White, 32 P-H Tax Ct. Mem. 81 (1963).

132. The suggestion that such an agreement is really a profit sharing arrangement rather than a sale and therefore not entitled to capital gain treatment reflects a broader question. A sale of good will for a present single payment, usually determined on the basis of anticipated earnings, in a sense also is an arrangement for a share of future earnings. The single payment is little more than the present capitalized equivalent of the future profits. Is the difference in payment - in one amount rather than in installments - or is the difference in accuracy of computation - on the basis of actual earnings experience rather than through an advance guess - sufficient to warrant capital gain treatment in one case and its denial in the other, where in both cases the seller has otherwise parted with all interest in the asset in such manner that it has come completely under the control of the buyer? This question is symptomatic of an even deeper dilemma: the problem of determining what is a capital asset and of distinguishing between property which is no more than future income reduced to present worth - and therefore not a capital asset and property which falls into the capital asset category. In the context of a bargain between parties at arms' length, all good will is an estimate of future income reduced to present worth. Indeed, in a basic economic sense, the same may even be said of the worth of tangible property beyond its scrap value.

133. Rev. Rul. 58-402, 1958-2 CuM. Bull. 15.

134. Mark L. Grinsten, P-H Tax Ct. Mem. I 64.051 (Feb. 28, 1964).

The excess of face amount over present value can be found to be ordinary income on two grounds: (1) After being taxed on the sales proceeds at their present worth, the proceeds acquire a tax basis in the amount of the present worth as an investment in the practice. That investment may then be amortized over the life of the payments, and the excess may be treated as a return on the investment. (2) The future payments are income after recovery of basis, and, since there is no sale or exchange in the process of receiving those payments, the excess cannot be capital gain. 
worth because of their contingent nature or the absence of a cash equivalent for the obligation to make those payments, the transaction would not have been considered closed at the time of sale and the payments would have been treated entirely as capital gain received on the sale. ${ }^{135}$ This could well have been the outcome where the payments depend on the uncertainties of profit in a professional practice. ${ }^{136}$ Now, however, this opportunity for tax avoidance is substantially curtailed as a result of a recently adopted statutory provision, ${ }^{\mathbf{1 3 7}}$ and the prevention of such avoidance should no longer be a factor in deciding how to treat such a transaction.

\section{Professional Associations}

With the objective of enabling professional practitioners to adopt a form of organization which would qualify as a corporation for federal income tax purposes, ${ }^{138}$ in order that they may enjoy the tax concessions tendered employee benefits, ${ }^{139}$ more than thirty states have enacted statutes during the past three years which variously authorize the creation of professional associations or corporations. ${ }^{140}$ The interaction between these new forms and the element of good will suggests two questions, one concerned with the effect of these forms on the tax treatment of good will disposition, and the other with the effect of our analysis of professional good will on the recognition of these forms as corporations.

The use of a corporate form as an organizational medium does not alter the underlying personal and economic factors which characterize the practice of a profession and the development of professional good will. The nature of the relationship between the practitioner and his client, the characteristics of which define the good will flowing from one to the other, is in no way affected by the form of organization under state law. ${ }^{141}$ In determining the transferable character of the good will of the practice and the conditions required to

135. Burnet v. Logan; 283 U.S. 404 (1931) ; Commissioner v. Carter, 170 F.2d 911 (2d Cir. 1948).

136. Cassatt v. Commissioner, 137 F.2d 745 (3d Cir. 1943).

137. INT. REv. CoDE of 1954, § 483, added by $\S 224$ of the Revenue Act of 1964, Pub. L. No. 272, 88th Cong., 2d Sess. (Feb. 26, 1964).

138. For the requirements on which recognition of a corporation is conditioned see Treas. Reg. $\$ 301.7701-2$ (1960); United States v. Kintner, 216 F.2d 418 (9th Cir. 1954). 139. The principal incentive is the possibility of adopting a qualified employees retirement plan, the contributions to which are nontaxable to the employee but deductible by the employer under INT. Rev. CoDE of 1954, \& 404. Cf. the Self-Employed Individuals Tax Retirement Act of 1962, INT. REv. CoDE of 1954, § 401.

140. Many of these statutes are listed in Grayck, Professional Associations and the Kintuer Regulations: Sone Answers, More Questions, and Further Comments, 17 Tax L. REv. 469 n.1 (1962). Since that time such statutes were also enacted by California, Idaho, Indiana, Michigam, Missouri, Montana, Nevada, New Jersey, New Mexico, North Dakota, and Utah. For discussions of some of the problems in these statutes, see Bittker, Professional Associations and Federal Income Taxation: Some Questions and Comments, 17 TAx L. Rev. 1 (1961); Alexander, Some Problems of a Professional Association, 13 W. Res. L. Rev. 212 (1962) ; Note, Professional Corporations and Associations, 75 HARV. L. REv. 776 (1962).

141. Cf. D. K. McDonald, 3 T.C. 720 (1944). 
make a disposition of it, the nontax standards heretofore formulated should therefore be applied with the same force to these relatively novel forms as to those more traditional. And in judging whether a purported transfer of the good will results in capital gain or ordinary income, the applicable tax standards and considerations should likewise be the same.

If, for example, a practice conducted in corporate form were sold, in toto, a disposition, to be entitled to recognition as a sale of the good will, should include an arrangement which restricts the capacity of the sellers, either individual or corporate, from interfering with the shift of the good will; a covenant not to compete or an acceptable equivalent ought also to be required. These conditions should apply whether the total disposition is through a corporate sale of all its assets or by the individuals' sale of all their interests in the corporation. If one individual alone sells his corporate interest, an effective disposition of his good will should require assumption of similar restrictions by him, just as though he were disposing of a partnership interest in a professional practice. If the individual disposes of only part of his corporate interest, the same considerations should apply in determining for tax purposes whether he has sold good will as have been discussed with respect to a purported partial disposition of professional good will in other contexts. If a senior joins with one or more juniors to engage in a group practice in corporate form, and he transfers all his assets, including his good will, to the corporation, he theoretically retains no residue of good will, his only interest thereafter consisting of his proportionate equity as a shareholder. Superficially it might be argued that a total disposition of the good will had been made. Functionally, however, the senior retains the same position with respect to client patronage as if a partnership had been formed, and in reality the disposition remains of the type heretofore classified as partial rather than total.

Looking at the situation from the other side, i.e., the implications of the proposed analysis on the success of these new forms in achieving recognition as corporations, two observations are pertinent. First, free transferability of interests is one of the hallmarks of a corporate entity, and the Treasury Regulations accept as weighing in favor of corporate status for tax purposes a modified form of transferability under which a member of such an organizaiton is allowed to transfer his interest to an outsider only after first having offered it to his colleagues at its fair market value. ${ }^{142}$ The point has also been made that fair market value cannot be paid if the member's good will is included in the offer, unless payment is also made for that good will. ${ }^{143}$ Here, in both these respects, the nontax standards discussed previously should be applied, to determine whether there has been a transfer of good will and whether, therefore, a payment for it is involved.

Second, and more important, the nontax standards illuminate the extent to which, as a matter of fact, a practitioner's assets can be put into a corporation. If a transfer is to be made in accordance with those standards, an appro-

142. Treas. Reg. $\$ 301.7701-2$ (e) (2) (1960).

143. Bittker, supra note 140 , at 19-20. 
priate severance must be made between the practitioner and his good will. Such a severance does not actually occur where a practitioner merely becomes a member of such a corporate organization; rather, there is only a partial disposition which, examined as of the time the organization is formed, is unascertainable in extent. In such an arrangement, the practitioner's good will has not been separated from him, despite any paper appearance to the contrary. Since good will in a professional practice is at least a major asset, if not the most important one, there is ground for claiming that, in substance, such an organization is not an effective embodiment of the practice and ought to be disregarded. ${ }^{144}$ If this were a matter of first impression, therefore, such an organization, whether formed under a professional "association" or a professional "corporation" statute, ${ }^{145}$ might be disregarded. ${ }^{146}$ However, existing $\operatorname{tax}$ standards relating to the recognition of an organization as a corporation confer corporate tax status in analogous situations in which the principal assets of the organization are inseparably bound to certain individuals, ${ }^{147}$ and it would be inconsistent and discriminatory to apply contrary criteria here. To treat the professional corporation differently, by subordinating doctrine which otherwise is accepted and applied, would only extend the contradictory patchwork. $^{148}$

\section{The Tine and Amount of Capital Gain}

Determination of the time at which capital gain occurs should depend on the point at which a qualifying severance and disposition of good will takes place. In the event of a total disposition of good will, the point of capital gain realization coincides with the time of disposition. Where the transfer of professional good will is in an immediate total disposition, and if such a transaction is recognized as resulting in capital gain, the point of disposition and realization of capital gain clearly occurs at the outset. The result should be the same, moreover, where the payments, in a transaction which can be identified as an immediate total disposition, are made in installments. Similarly, if there is a deferred total disposition prior to which no' payments are made, the point

144. Cf. Treas. Reg. $\$ 301.7701-2$ (a) (1) (1960).

145. See note 140 supra.

146. This in effect is the direction of the recent proposed amendments to the "Kintner" Regulations, dealing specifically with such professional organizations. See Proposed Treas. Reg. $\$ \S 301.7701-1(\mathrm{~d})$ and 301.7701-2(h), 28 Fed. Reg. 13751 (Daily Ed. Dec. 17, 1963).

147. In the area of the professions, defined broadly as in note 1 supra, the incorporated insurance agency is an examlpe. Another, similar in substance, is the incorporated entertainer. Cf. INT. REv. Code of 1954, § 543(a) (5) ; Jack Benny, 25 T.C. 197 (1955); Taubman, Motion Picture Co-Production Deals and Theatrical Business Orgastization, 11 TAX L. REv. 113, 117 (1956).

Cf. National Carbide Corp. v. Commissioner, 336 U.S. 422 (1949), which despite the following obscrvation, recognized the separate existence of a corporation: "Undoubtedly the great majority of corporations owned by sole stockholders are 'dummies' in the sense that their policies and day-to-day activities are determined not as decisions of the corporation but by their owners acting individually." Id. at 433 .

143. But cf. Note, 75 Harv. L. Rev. 756, 785 (1962). 
of disposition and realization of capital gain would come at the end of the projected intervening period.

Where a partial disposition is made, either by a participant who undertakes a distant retirement obligation or one who makes no retirement commitment, the nontax standards indicate that no disposition is likely to have occurred during the intervening period of continued participation by the alleged transferor. In accordance with the analysis proposed herein, no capital gain is realized on any payment received during that period. Intervening installment payments would be treated in the same manner where they were made in connection with a deferred total disposition, unless the transaction could be identified as a total disposition deferred only as a financing mechanism.

This analysis has a bearing on the amount of good will involved in the disposition and the extent of the capital gain. For example, if a physician buys a practice and pays $\$ 20,000$ for the good will, and if he then purports to make an immediate sale to a new partner of one-half of his good will, committing himself to sell the other half ten years later, the question arises as to the reduction of the amount of capital gain on the ultimate sale by the cost of the good will. Although no ascertainable disposition can be recognized until the end of the 10-year period, a partial consumption of the original good will may nevertheless occur during that period. Although it is not possible to measure the extent to which that good will has been imperceptibly shifted or consumed by, for example, the association of the men and their joint enjoyment of the good will, the judgment of the parties, as shown by their agreement, is that at the end of the ten-year period the physician has only half of his original good will to sell, the balance of the good will having been consumed or shifted in some other fashion. His remaining basis for the good will sold at the end of that period therefore arguably might be said not to exceed a like proportion of his original basis, which would be one-half his cost or $\$ 10,000.140$ If there is a discrepancy between the quantum of good will remaining in such a transferor and the portion specified in the concluding phase of the arrangement, as may often be the case, it may be treated as shifted to the other participant as an inseparable part of the compound of benefits which they have arranged up to that point rather than as part of the consideration for which the concluding sales payment is made. In any event, the inexactitude and difficulty of measurement is the making of the taxpayer, and it may be deemed not unjust to place on him the burden of the consequential difficulties.

\section{ConCLUSION}

If the disposition of professional good will is analyzed to discover what happens as a matter of fact in such a transaction, and if established tax doctrine is applied to these facts, it is difficult to justify capital gains treatment for the resulting income. Even the immediate total disposition is likely to be so inseparably submerged in a covenant not to compete or some substitute

149. Cf. Treas. Reg. $\S 1.61-6(a)$ (1957) ; Commissioner v. Cedar Park Cemetery Assn., 183 F.2d 553 (7th Cir. 1950). 
that it ought to be regarded as inherently ineligible for capital gain treatment.

Assuming acceptance of the debatable premise that good will ought to be treated as a capital commodity in the case of an industrial or mercantile enterprise, it does not follow that professional good will is of the same quality and deserves the same treatment. The assets of the industrial or mercantile business have an existence independent of the identity of the owners, so that the good will of the business usually adheres to those assets and can be transferred with them. Professional good will, by contrast, normally bears little or no relation to other properties in the practice, but is bound to the person of the practitioner and can be transferred significantly only through his personal efforts, whether exercised in a negative or affirmative fashion. But the term "good will" is used indiscriminately without regard to these factual distinctions, as reflected in a widespread, thoughtless submission to the semantic fallacy that the subject at hand is the same because it is called by the same name. The view is now well entrenched in the tax law that professional good will is a capital asset.

This factual and doctrinal error ought not to be compounded by extending it through a like process of semantic transference and intellectual laxity to partial dispositions of professional good will. These are transactions which more graphically exhibit their character as ordinary income and demonstrate more clearly the incongruity in tax principle of the application to them of capital gains classification. Here precedent is still in the formative stages and the opportunity is still open to influence the shape which the governing tax law is to take. The Watson and Rees cases ${ }^{150}$ fortunately are as yet only suggestive of a possible viewpoint rather than illustrative of established law.

In the effort to mold the developing law in the area, the Internal Revenue Service bears the principal responsibility. To date its performance in problems of professional good will has been piecemeal and incoherent. It should instead issue, as quickly as possible, a comprehensive directive concerned with the principal forms in which these problems appear, presenting the transactions in their proper factual perspective and drawing conclusions as to tax treatment for which the support of settled principles can be demonstrated. Such a directive would add to the persuasive weight and influence of Government contentions made in litigation, and would also serve the more general function of guiding not only the courts but also taxpayers, their counsel, and the personnel of the Service.

In this connection two related matters merit congressional attention. The Code, in Sections 736 and 751, makes capital gain available on a disposition of good will by a partner. This is a discriminatory result if the same opportunity is not available to the individual practitioner and to one who practices in the new corporate forms. Uniformity of treatment should be prescribed regardless of the organizational form of practice. One means of attaining that objective would be a provision which simply declared that professional good

150. 35 T.C. 203 (1960); 187 F. Supp. 924 (D. Ore. 1960), aff'd per curian, 295 F.2d 817 (9th Cir. 1961). 
will is a capital asset. Rather than spawning spurious capital gains and further distending the tax law, however, it would be preferable to take a contrary approach and recognize that a disposition of professional good will, to the extent that it anticipates future ordinary income, tends to concentrate that income in a single year or some other short period and may give rise to a greater tax burden than would be incurred over the longer term of its natural realization. To deal with this situation, which is the real harshness in treating a professional good will disposition as an ordinary income transaction, the needed response is a statutory income-averaging device. ${ }^{151}$ Such a provision would bring a uniformity of treatment regardless of organizational form, allowing both total and partial dispositions to be recognized as ordinary income transactions. By comparison, as a substitute measure to mitigate the same burden, the capital gains treatment now conferred by the courts and to a lesser extent by the Code, is overly bountiful in permitting a tax at less than ordinary income rates and in an amount less than probably would be paid if the income were realized in its normal course.

151. Cf. President Kennedy's special message on tax reduction and reform, Jan. 24, 1963 , proposing a broadly applicable income averaging provision to be included in the then proposed Revenue Act of 1963, and which was adopted as $\$ \S 1301-1305$ of the 1954 Code by Sec. 232 of the Revenue Act of 1964, Pub. L. 272, 88th Cong., 2d Sess., (Feb. $26,1964)$. 